\title{
Antihypertensive Assay-Guided Fractionation of Syzygium polyanthum Leaves and Phenolics Profile Analysis Using LC- QTOF/MS
}

\author{
Azlini Ismail1,*, Erlena Nor Asmira Abdul Rahim², Muhammad Nor Omar'², Wan Amir Nizam Wan Ahmad ${ }^{3}$
}

Azlini Ismail ${ }^{1, *}$, Erlena Nor Asmira Abdul Rahim², Muhammad Nor Omar', Wan Amir Nizam Wan Ahmad $^{3}$

'Department of Fundamental Dental and Medical Sciences, Kuliyyah of Dentistry, International Islamic University Malaysia, Indera Mahkota, 25200 Kuantan, Pahang, MALAYSIA.

${ }^{2}$ Department of Biotechnology, Kuliyyah of Science, International Islamic University Malaysia, Indera Mahkota, 25200 Kuantan, Pahang, MALAYSIA.

${ }^{3}$ School of Health Sciences, Universiti Sains Malaysia, Health Campus, 16150 Kubang

Kerian, Kelantan, MALAYSIA

\section{Correspondence}

\section{Azlini Ismail}

Department of Fundamental Dental and Medical Sciences, Kuliyyah of Dentistry, International Islamic University Malaysia, Bandar Indera Mahkota, 25200 Kuantan,

Pahang, MALAYSIA.

Phone no: +014-5010081

Email: dr_azlini@iium.edu.my History

- Submission Date: 27-07-2020;

- Review completed: 26-08-2020;

- Accepted Date: 02-09-2020

DOI : 10.5530/pj.2020.12.227

Article Available online

http://www.phcogj.com/v12/i6s

\section{Copyright}

(c) 2020 Phcogj.Com. This is an openaccess article distributed under the term of the Creative Commons Attribution 4.0 International license.

\begin{abstract}
Introduction: Syzygium polyanthum leaves extract that contains gallic acid as the major phenolic compound has shown significant antihypertensive effect, however the amount of gallic acid was inversely-related with magnitude of this effect. This study aimed to conduct bioassay-guided fractionation of $S$. polyanthum leaves with gallic acid as a reference compound, and to screen for other possible compounds responsible for the antihypertensive effect. Methods: S. polyanthum leaves were extracted using n-hexane, ethyl acetate, methanol, and water. The most active crude extract was fractionated using column chromatography and analyzed for total phenolic content (TPC) $(n=3)$. Crude extracts and the derived fractions were intravenously administered into pentobarbital-anaesthetized Spontaneously Hypertensive rats $(n=5)$ for recording of blood pressure parameters. Liquid Chromatography-Quadruple Time-Off-Flight/Mass Spectrometry was used for determination of chemical composition. One-way and two-way ANOVA were used for statistical analysis using GraphPad ${ }^{\circledR}$ PRISM Version 6. Results: Fractionation of aqueous S. polyanthum leaves extract (ASP) afforded nine fractions, later combined into three fractions (F1ASP, F2ASP, and F3ASP) based on the thinlayer chromatography profiles. ASP has the highest TPC while F2ASP has the lowest TPC. All fractions exhibited significant antihypertensive property, but F2ASP was the most active fraction. Few phenolics with related antihypertensive effects such as 1-galloyl glucose (a gallic acid-derivative majorly found in F2ASP and F3ASP), and other compounds such as polydatin, sesamol, brazilin, eugenol, ellagic acid, kukoamine A, and cyclocurcumin were found across all active fractions. Conclusion: These phenolics may partly contribute to the antihypertensive effect of $S$. polyanthum leaves, thus further isolation study is recommended.
\end{abstract}

Key words: Antihypertensive, Bioassay-guided, LCMS, Syzygium polyanthum, Total phenol content (TPC).

\section{INTRODUCTION}

Hypertension is a major public health problem. According to the World Health Organization ${ }^{1}$, an uncontrolled rise in blood pressure may predispose a patient to a heart attack which will eventually lead to heart and kidney failures, stroke, and cognitive impairment. It was estimated that the worldwide prevalence of hypertension exceeded 1.3 billion, representing $31 \%$ of all adults. ${ }^{2}$ Throughout the years, the condition of raised blood pressure among the hypertensive patients was uncontrolled. ${ }^{3}$ While there are available antihypertensive drugs in the market, the global condition remains stagnant since the treatment is expensive, thus an average or a poor society did not afford to receive the best treatment regime. In addition, the concomitant drugs' side effects such as dizziness, abnormal heart rate, sore throat, sexual dysfunction, thrombocytopenia, and hyperglycemia ${ }^{4}$ are undesirable, and this untoward reaction actually occurs more easily when drugs are used in combination. ${ }^{5}$ The expensive cost and the side effects of the currentlyavailable antihypertensive drugs have enforced the research for new alternative antihypertensive drugs which should be at least equally effective, but yet inexpensive.

Some natural compounds from medicinal plants were found to exhibit significant antihypertensive effect ${ }^{6}$, however, there is also a huge number of potential medicinal plants with antihypertensive properties that remains to be explored. Syzygium polyanthum (Wight) Walp, also known as 'salam' or 'serai kayu' is one of the medicinal herbs that is traditionally consumed as an alternative treatment for reducing blood pressure among Malay folks. S. polyanthum has been known as an antihypertensive medicinal plant and this is strongly supported by previous findings. Sukrasno et $a l^{7}$ reported the hypotensive effect of orally-administered aqueous extract of S. polyanthum leaves in normotensive Wistar rats. S. polyanthum leaves extracts have shown a significant reduction in blood pressure of anaesthetized Spontaneously Hypertensive Rats (SHR) and normal Wistar Kyoto (WKY) when intravenously administered. ${ }^{8}$ When fed orally, $S$. polyanthum leaves extract significantly reduced the systolic blood pressure in SHR., ${ }^{9,10}$ Histological studies showed significant improvement in Bowman's capsule and glomerulus morphology of 
treated SHR's kidney, comparable to normal kidney structure and slight improvement of pedicels and thoracic aorta. ${ }^{10,11}$

Ramli et al ${ }^{11}$ suggested that the reduction in systolic blood pressure (SBP) in hypertensive rats might be due to the major composition of phenolics in the extract. Ismail et $a l^{9}$ showed the presence of gallic acid, a major phenolic compound present in S. polyanthum leaves extract. Gallic acid was previously reported to normalize blood pressure of diabetic rats ${ }^{12}$ and attenuate hypertension in NG-nitro-L-arginine methyl ester-induced hypertensive rats. ${ }^{13}$ However, our previous study showed there was no correlation between the amount of gallic acid with the magnitude of antihypertensive effect for the tested $S$. polyanthum leaves extracts, suggestive of the presence of synergism between compounds that contributes to the net antihypertensive effect. ${ }^{9}$ Therefore, this study aimed to perform bioassay-guided fractionation of S. polyanthum leaves to screen for other potential bioactive compounds responsible for its antihypertensive effect.

\section{MATERIALS AND METHODS}

\section{Plant authentication}

The leaves, flowers, buds, and stem parts of $S$. polyanthum were sent for authentication at UKMB Herbarium, Faculty of Science and Technology, Universiti Kebangsaan Malaysia. The plant was verified as Syzygium polyanthum Wight Walp. on $2^{\text {nd }}$ May 2017. The voucher herbarium specimen (PIIUM 0282) was deposited in Herbarium, Kulliyyah of Pharmacy, International Islamic University Malaysia, Kuantan, Pahang, Malaysia.

\section{Animal}

Seventy-five of 3-month old male Spontaneously Hypertensive Rats (SHR), weighing around 250 to 280 grams were placed in standard rat cages and acclimatized for 7 days in standard environmental conditions ( $25^{\circ} \mathrm{C}$ with $60-70 \%$ humidity) on a 12 -hour light-dark cycle. Tap water and rat pellet were given ad libitum and the animal bedding was changed once in a week. All experimental protocols regarding the animal study were approved by the Animal Ethics Committee, Universiti Sains Malaysia (USM/Animal Ethics Approval/2016/ (102) (757).

\section{Sample extraction}

Two kg of S. polyanthum leaves were collected from Taman Pertanian Jubli Perak Kuantan, Pahang, Malaysia. The leaves were left dried in a drying cabinet for a week at $50{ }^{\circ} \mathrm{C}$. After a week, the dried leaves were ground into powder using a laboratory blender prior to extraction. The powdered sample was extracted using ultra-sound assisted extraction (UAE) method as described by Rahim et al . ${ }^{14}$ This method enhances solvent penetration through plant cells with the aid of sound waves, ${ }^{11}$, 15,16 and usually provides sufficient yield for phenolic compounds. ${ }^{17}$ Hot distilled water $\left(80{ }^{\circ} \mathrm{C}\right)$ and also solvents with varying polarities including n-hexane, ethyl acetate, and methanol were used to prepare different crude extracts of $S$. polyanthum leaves.

For each sequential solvent extraction method, $250 \mathrm{~g}$ of powdered $S$. polyanthum leaves were initially soaked in $700 \mathrm{ml}$-hexane. The soaked sample was then placed in a bath-sonicator (WiseClean, Switzerland) at $24^{\circ} \mathrm{C}$ by frequency range from 40 to $80 \lambda$ for 30 minutes and then filtered with Whatman filter paper No.1. The filtrate was then concentrated using a rotary evaporator (Buchi R-200, Switzerland). This concentrated filtrate was designated as hexane extract of $S$. polyanthum (HSP). The remaining powder residue from hexane extraction was then soaked with $700 \mathrm{ml}$ of ethyl acetate, and then it was also sonicated using the bath-sonicator (WiseClean, Switzerland) at $24^{\circ} \mathrm{C}$ by frequency range from 40 to $80 \lambda$ for 30 minutes. The soaked sample was then filtrated with Whatman filter paper No. 1, and was subsequently left dried in the fume hood (Rico, Malaysia). This concentrated filtrate was designated as ethyl acetate extract of $S$. polyanthum (ESP). Next, the remaining residue from the ethyl acetate extraction was then soaked in methanol for three cycles of $700 \mathrm{ml}$ (first cycle), $400 \mathrm{ml}$ (second cycle), and 400 $\mathrm{ml}$ (third cycle), respectively. In between each cycle, the soaked sample was sonicated using the bath-sonicator (WiseClean, Switzerland) at 24 ${ }^{\circ} \mathrm{C}$ by frequency range from 40 to $80 \lambda$ for 30 minutes and then filtrated with Whatman filter paper No. 1. The filtrates from the three cycles were then combined and then concentrated using a rotary evaporator. This concentrated filtrate was designated as the methanol extract of $S$. polyanthum (MSP).

Meanwhile, for water extraction, another $250 \mathrm{~g}$ of powdered sample was used and soaked in a pre-heated distilled water at $80^{\circ} \mathrm{C}$ using a hot plate for three cycles of $700 \mathrm{ml}$ (first cycle), $400 \mathrm{ml}$ (second cycle), and $400 \mathrm{ml}$ (third cycle) of distilled water for 30 minutes. In between each cycle, the soaked sample was also sonicated using the bath-sonicator (WiseClean, Switzerland) at $24^{\circ} \mathrm{C}$ by the frequency range from 40 to $80 \lambda$ for 30 minutes and then filtrated with Whatman filter paper No. 1 . The three filtrates from each cycle were combined and then stored in a $-80^{\circ} \mathrm{C}$ freezer before being lyophilized using a freeze dryer (CHRIST Model Beta 1-8 LO, Germany) for 12 days. This lyophilized sample was designated as the aqueous extract of $S$. polyanthum (ASP). All samples were stored at $-20{ }^{\circ} \mathrm{C}$ in a freezer (Wiseclean, Switzerland) before further use.

\section{Bioassay-guided fractionation}

Since ASP was the crude extract with the most prominent antihypertensive effect, it was then subjected to fractionation. Before fractionation, the thin layer chromatography (TLC) is performed to study the characteristics of the extract and to optimize the solvent system to achieve a good separation during fractionation. ${ }^{18}$ TLC plates $(8 \times 8$ ") were firstly cut into a measurement of $10 \mathrm{~cm} \mathrm{x} 2 \mathrm{~cm}$ and were allowed to dry overnight at $37^{\circ} \mathrm{C}$ in an incubator oven (Memmert, Germany). The crude extract was firstly developed with $100 \%$ n-hexane, ethyl acetate, dichloromethane, methanol, and acetonitrile. The crude extract was then run with the solvent system of ethyl acetate: methanol: acetonitrile (8:1:1) with an additional one drop of formic acid. The additional one drop of formic acid was used to enhance the separation of the four spots. Gallic acid was used as a reference compound (standard) based on finding from our previous study that gallic acid was found as a major phenolic compound in the aqueous and methanolic extracts of $S$. polyanthum leaves. ${ }^{9}$ The spots and the standard were visualized under UV lamp (Leybold Didactic GmbH, Germany) of short and long wave and by ferric chloride spraying detection reagent.

For fractionation, a $30 \mathrm{~cm}$-height of silica column using a $25 \mathrm{~mm}$ glass column was prepared by mixing $35 \mathrm{~g}$ of silica gel 60 (0.063-0.200 mesh) with $100 \%$ ethyl acetate. The column was allowed to stand overnight for complete packing. ASP slurry was prepared in a combined solvent mixture of methanol and water (50:50) to enhance the solubility of methoxylated and hydroxylated compounds. ${ }^{19}$ Then, the ASP slurry was run in the column chromatography using a gradient elution technique with a binary solvent system of ethyl acetate and methanol, allowing polarity changes during the fractionation. Gradient elution usually offers better speed, separation, and retention reproducibility compared to isocratic elution for wide range polarities of organic compounds. ${ }^{20}$ The gradient solvent system of ethyl acetate $(100 \%)$, ethyl acetate: methanol (7:3), ethyl acetate: methanol (5: 5), ethyl acetate: methanol (3:7), and methanol (100\%) were consequentially employed and finally, the column was washed with $100 \%$ methanol. Nine fractions were collected in a $15 \mathrm{ml}$ centrifuge tube and characterized by TLC profiling with a solvent system of ethyl acetate: methanol (9.5:0.5) with a drop of formic acid. The spots were visualized using a UV lamp, 50 $\%$ sulphuric acid spraying reagent, vanillin-sulphuric acid reagent and ferric chloride spraying detection reagent. These spraying reagents were 
prepared according to the methods stated in Pirrung ${ }^{21}$ and Mohrig et al .$^{22}$ Similar fractions (similar TLC profile) were pooled and combined to give the final three fractions designated as F1ASP, F2ASP, and F3ASP. These fractions were then dried in an incubator oven (Memmert, Germany) and stored at $-20^{\circ} \mathrm{C}$ in a refrigerator (SuperFreezer $340 \mathrm{~W}$ $1 \mathrm{D}$, Korea) for further analysis.

\section{Determination of antihypertensive effect of crude extracts and fractions}

This in vivo antihypertensive study was conducted based on several previous studies. ${ }^{8,23,24}$ A BIOPAC Data Acquisition System, attached to an arterial pressure transducer with an amplifier recorder (MP30, BIOPAC Data Acquisition System) was employed for measurement of blood pressure parameters and the data were displayed using BIOPAC Student Lab Pro ${ }^{\circledR}$ v3.6.7.

Each rat was weighed using a laboratory weighing balance and anaesthetized with $60 \mathrm{mg} / \mathrm{kg}$ sodium pentobarbital via intraperitoneal injection. The reflex of the rat was checked by pinching the tail and the toe. The rat was placed in a rat's container until no reflex reaction occurred. Later, the rat was brought to the surgery table before performing a tracheotomy. An additional amount of $10 \mathrm{mg} / \mathrm{kg}$ sodium pentobarbital was given throughout the experiment to maintain the anaesthetic condition whenever necessary. The body temperature of rats was maintained at $37 \pm 1{ }^{\circ} \mathrm{C}$ using an overhead lamp. The skin on the anterior side of the neck was carefully cut-off using a surgical scissor. A small incision was made $(1.5-2 \mathrm{~cm})$ on the skin layers of the anterior side of the neck. A slit incision was made on the rat platysma muscles. By using two forceps with teeth, the skin was separated via blunt dissection technique while taking extra precautions not to disturb the larynx, hyoid bone, and thyroid cartilage. The trachea was then identified and forceps were used to slightly pull up the trachea and then a thread was eventually passed underneath it. The front part of the trachea was then half-incised for the insertion of modified intravenous drip tubing. The tube was thick with a length around 3 to $4 \mathrm{~cm}$. The thread under the trachea was then used to fix the inserted tube to the trachea. Tracheotomy was performed to aid the respiration process since the employed sodium pentobarbital usually increases the bronchial secretion. Continuous monitoring of the rats' respiration was performed throughout the experiment.

After tracheotomy, cannulation of the carotid artery was performed. The dark red, elastic, rounded, and thick vessel of the carotid artery was identified along the vagus nerve which was white-in-color on either side of the trachea. Separation of the vagus nerve, connective tissue, and longus capitis (a longitudinal bundle of muscle located adjacent to the trachea) was carried out. The cephalic end of the carotid artery was tied with a thread and another end near to the heart was temporarily clamped with a bulldog clamp. These were done to prevent misreading of actual blood pressure due to the division of pressure between the brain and carotid cannula. ${ }^{23}$

The carotid artery was half-incised, and then a cannula, pre-filled with heparinised saline $(5 \mathrm{IU} / \mathrm{ml})$ that was connected to a pre-calibrated pressure transducer was inserted into the carotid artery. The heparinised saline was a solution mixture of heparin and $0.9 \%$ normal saline. Another end of the cannula was connected to a three-way stopcock, attached to a saline-filled tuberculin syringe. After the cannulation, the bulldog clamp was released slowly. Free transmission of pressure in the cannula must be ensured for continuous monitoring of accurate mean arterial pressure (MAP), systolic blood pressure (SBP), and diastolic blood pressure (DBP) that can be seen at the data acquisition system (Biopac System, USA).

A small incision $(1-2 \mathrm{~cm})$ was made on the epidermis of the right tight where the left jugular vein was located. A matrix of connective tissue was cleaned carefully via blunt dissection using two forceps with teeth. The jugular vein was differentiated from the nerve fibre and a catheter was cannulated before drug administration. During cannulation, threads were first passed under the vein. Once the vein has been isolated, the upper part of the rounded-vein was then half-incised to allow the insertion of a cannula, filled with heparinised saline (5 IU/ $\mathrm{ml}$ ). The thread was then tightened at the upper part (the part closer to brain) after the cannula has been inserted. Another thread was used to tie the vein along the inserted catheter. The cannulation line was flushed with heparinised saline $(0.2 \mathrm{ml})$ to prevent thrombosis. ${ }^{23}$

To determine the crude extract with the most prominent antihypertensive effect, the four crude extracts (ASP, HSP, ESP, and MSP) were dissolved in $0.9 \%$ normal saline to achieve dosages of 1,10 , 40 , and $70 \mathrm{mg} / \mathrm{kg}$ based on a previous related paper by Ismail et al.$^{8} \mathrm{In}$ the subsequent study to determine the most active fraction, the fractions were dissolved with the same vehicle as in the previous experiment with the crude extract and prepared to achieve the dosages of 10, 20,30, 40, 50 , and $60 \mathrm{mg} / \mathrm{kg}$. All prepared extracts and fractions were vortexed using a vortex machine (PV1 Grant-bio, England) immediately before use. Normal saline $(0.9 \%)$ was used as negative control while captopril at $5 \mathrm{mg} / \mathrm{kg}$ was used as a positive control drug according to Abdulazeez et al . ${ }^{24}$ Captopril is an angiotensin-converting enzyme inhibitor that is used as one of the first-line antihypertensive drugs for the treatment of hypertension and congestive heart failure. Captopril was prepared by dissolving the drug into $0.9 \%$ normal saline. A fixed volume of $0.2 \mathrm{ml}$ for the extracts and fractions at increasing dosages were sequentially administered into each rat $(n=5)$. The baseline for all blood pressure parameters such as MAP, SBP, and DBP of rats were ensured to return to the baseline value before administration of each subsequent dosage.

\section{Total phenolic content analysis}

The total phenolic content of the ASP crude extract and the three derived fractions (F1ASP, F2ASP, and F3ASP) were determined using Folin-Ciocalteu assay with ACS reagent grade gallic acid as a standard. Two-hundred $\mu$ of sample for ASP, F1ASP, F2ASP, F3ASP, and gallic acid (as a standard) were pipetted into individual test tubes. Eighthundred $\mu \mathrm{l}$ of distilled water and $500 \mu$ l of Folin's Reagent were added together into the test tubes containing-samples and standard. Each sample was prepared in triplicates. The standard was prepared from 30 to $200 \mu \mathrm{g} / \mathrm{ml}$ of gallic acid dissolved in AR methanol. All samples (ASP, F1ASP, F2ASP, and F3ASP) were prepared in $1 \mathrm{mg} / \mathrm{ml}$ of AR methanol. All of them were allowed to stand in the dark for 5 minutes. After that, $1.5 \mathrm{ml}$ of $20 \% \mathrm{w} / \mathrm{v}$ sodium carbonate $\left(\mathrm{Na}_{2} \mathrm{CO}_{3}\right)$ was added and all the mixtures were incubated at room temperature in a dark condition for 2 hours. Two $\mathrm{ml}$ of prepared mixtures of samples (ASP, F1ASP, F2ASP, and F3ASP) and standard (gallic acid, 30 to $200 \mu \mathrm{g} / \mathrm{ml}$ ) were then transferred into a plastic cuvette for measurement. The absorbance was measured at the wavelength of $760 \mathrm{~nm}$ against a blank (distilled water) using a UV-VIS spectrophotometer (Perkin Elmer, Malaysia). Blainski et al ${ }^{25}$ reported that the maximum absorption can be produced at this specific wavelength. Moreover, the long-wavelength absorption of the chromophores minimizes the interference of the sample matrix that is often coloured..$^{26}$ The measured absorbance for standard (gallic acid, 30 to $200 \mu \mathrm{g} / \mathrm{ml}$ ) and each respective sample in triplicates were averaged and a standard curve graph was plotted.

\section{LC-QTOF/MS analysis for identification of phenolic compounds in the most active crude extract and active fractions}

Identification of the compounds in the ASP, F1ASP, F2ASP, and F3ASP were conducted using a modified method described by Terpinc et al.$^{27}$ LC-MS instrument used was a Waters, VION Ion Mobility QTOF MS. HPLC system was a binary pump with solvent gradient of water (A) and 
acetonitrile (B): $99 \% \mathrm{~A}, 1 \% \mathrm{~B}$ from 0 to $0.5 \mathrm{~min} ; 65 \% \mathrm{~A}, 35 \% \mathrm{~B}$ from 0.5 to $16 \mathrm{~min} ; 0 \% \mathrm{~A}, 100 \% \mathrm{~B}$ from 16 to $18 \mathrm{~min}$; and $99 \% \mathrm{~A}, 1 \% \mathrm{~B}$ from 18 to $20 \mathrm{~min}$ ). Negative ion electrospray ionization (ESI) was used without solvent splitting. The sample was filtered by a filter membrane with a $25 \mathrm{~mm}$ diameter and $0.45 \mu \mathrm{m}$ pore size. Ten $\mu \mathrm{l}(1 \mathrm{mg} / \mathrm{ml}$ in methanol, HPLC grade Merck, Germany) of the sample was injected into the instrument. Reversed-phase HPLC (RP HPLC) separation was carried out using ACQUITY UPLC HSS T3 $(2.1 \times 100 \mathrm{~mm} \times 1.8 \mu \mathrm{m})$ column protected by guard column. The mass spectrometer was operated in negative ion mode with parameters: capillary voltage of $1.5 \mathrm{kV}$; start time of $0.00 \mathrm{~min}$ and end time of $20.00 \mathrm{~min}$; source temperature of $120^{\circ} \mathrm{C}$; desolvation gas flow of $350 \mathrm{~L} / \mathrm{h}$; column temperature of $40^{\circ} \mathrm{C}$; and flow rate of $0.60 \mathrm{ml} / \mathrm{min}$. All of the phytochemical compounds in the LC-MS were based on an accuracy of less than $5 \mathrm{ppm}$ mass error.

\section{Statistical analysis}

The recorded MAP, SBP and DBP changes were expressed as mean percent changes \pm standard error of mean (S.E.M). All statistical tests were analyzed using $\mathrm{GraphPad}^{\oplus}$ Prism Version 6 software. A two-way ANOVA test was performed to determine the significant differences between multiple doses of extracts and fractions. Unpaired T-test was done only to ensure there was no significant difference $(P>0.05)$ if the plateau effect occurred on high dosages. A post-hoc Sidak test was performed for multiple pairwise comparisons between the doses. The $\mathrm{ED}_{50}$ values for MAP, SBP, and DBP reductions by ASP and fractions were computed by the software based on the constructed dose-response curves. TPC was analyzed by one way ANOVA, followed by post-hoc Sidak multiple comparison test between the doses. All tests were twotailed and a $\mathrm{P}$ value less than 0.05 was considered significant $(\mathrm{P}<0.05)$.

\section{RESULTS AND DISCUSSION}

\section{Yield of extraction}

In total, $1.45 \mathrm{~kg}$ of dried $S$. polyanthum leaves used in this study. The mean average yield for HSP, ESP, MSP and ASP were $1.72 \pm 0.83 \%$, $3.62 \pm 1.97 \%, 6.39 \pm 1.25 \%$ and $5.00 \pm 2.59 \%$, respectively. It was observed that methanol gave the highest yield among the four extracts while hexane gave the lowest yield. In agreement with this finding, Jumaat $e t a l^{28}$ reported that their extraction with n-hexane, a solvent with a polarity index (P') of 0.1 gave low extraction yield as compared to methanol. Extraction with n-hexane is crucial to break down the cell wall which is coated with the non-polar phospholipids. ${ }^{29}$ Ethyl acetate, a solvent with a polarity index ( $\left.\mathrm{P}^{\prime}\right)$ of 4.4, dissolves any hydrophilic, lipophilic compounds and hydrophobic chain lipids such as waxes and fat ${ }^{29}$ while methanol is a solvent with a polarity index ( $\left.\mathrm{P}^{\prime}\right)$ of 5.1 that partially dissolves some other non-water soluble compounds ${ }^{30}$ and extracts polar compounds like sugars, amino acids, glycosides and phenolic compounds with low and medium polarity. ${ }^{31}$ Water, on the other hand, is a universal solvent that is widely being used in extracting phytochemicals from traditional medicine ${ }^{30}$. It mostly dissolves proteins, carbohydrates ${ }^{32}$, and glycosides. ${ }^{31}$ The extraction with water, a solvent with a polarity index ( $\left.\mathrm{P}^{\prime}\right)$ of 10.2 usually did not dissolve any hydrophobic hydrocarbon compound. This is perhaps the reason that the yield of water extract was lower as compared to methanol. Thus, optimal temperature $\left(80^{\circ} \mathrm{C}\right)$ and ultrasound wave from sonication in the ultrasound-assisted extraction technique plays an important role to enhance water as a solvent to permeate the plant cell wall..$^{15,33}$ Do et $a l^{32}$ and Dhawan and Gupta ${ }^{34}$ also showed a lower percentage yield of water extract compared to methanol. This was probably due to the non-solubility of neutral lipids (non-polar hydrophobic) in water, while methanol dissolves a higher amount of polyphenols compared to water due to its inherent efficiency to degrade cell wall comprising of non-polar components. Tiwari $e a^{30}$ suggested the presence of active polyphenol oxidase enzyme in water extract which may be responsible for degradation of some polyphenols in water extract, whereas the enzyme is non-active in methanol extract. This may justify the higher yield in methanol extract as compared to water extract.

\section{Bioassay-guided fractionation}

Fractionation was done on ASP, the most prominent crude extract found in the first phase of the antihypertensive study. When ASP crude extract and the reference compound (gallic acid) was run with TLC using a solvent system of ethyl acetate: methanol: acetonitrile (8:1:1) with one drop of formic acid, four different spots were visualized with good separation when viewed under the UV lamp and sprayed with $\mathrm{FeCl}_{3}$ reagent (Figure 1). These spots were identified with $\mathrm{R}_{\mathrm{f}}$ values of $0.21,0.24,0.66$, and 0.70 . Only a spot with an $R_{f}$ value of 0.21 appeared to be slightly-tailing. The reference compound, gallic acid resulted

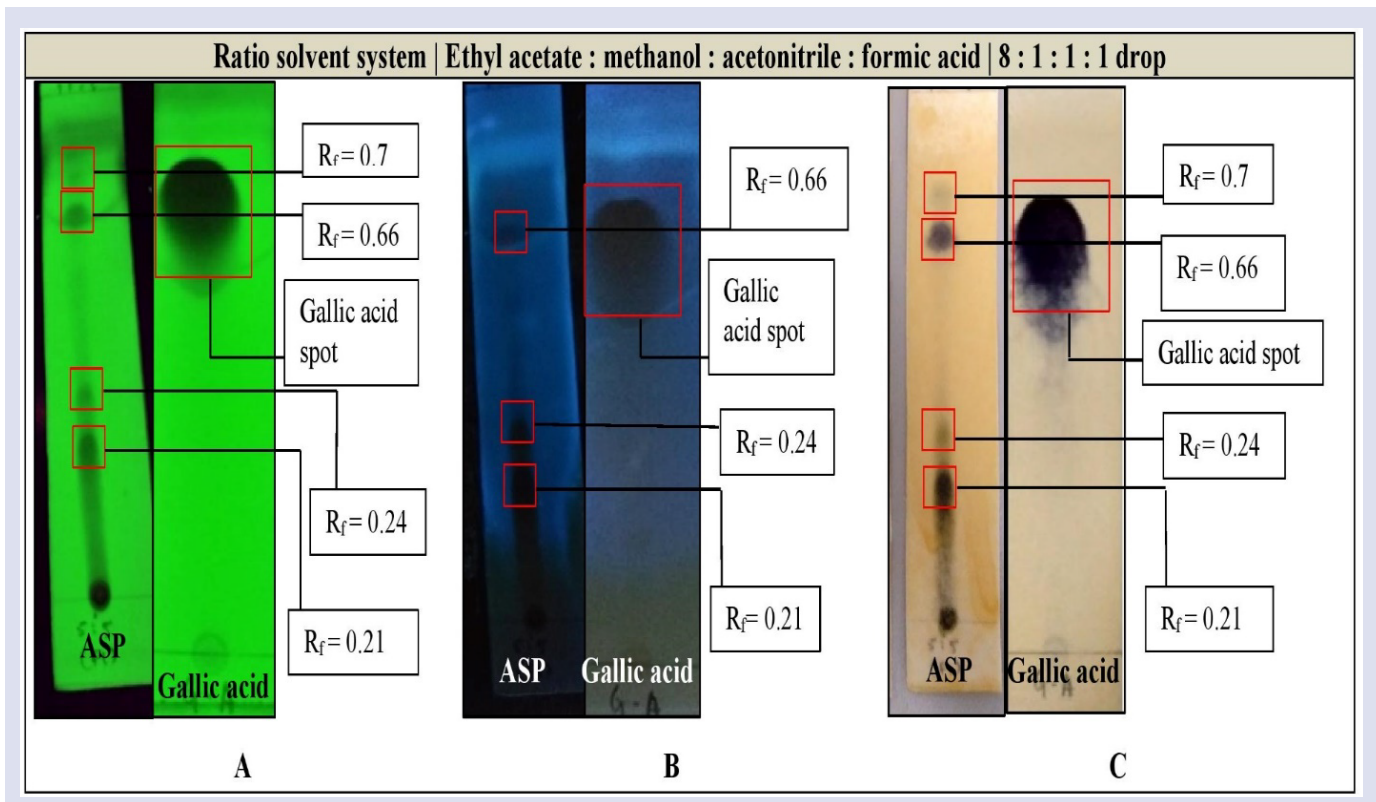

Figure 1: TLC profiles of ASP crude extract and reference (standard) gallic acid with the mobile system of ethyl acetate: methanol: acetonitrile (8:1:1) with one drop of formic acid with detection using A) UV short wave ( $254 \mathrm{~nm})$, B) UV long wave $(365 \mathrm{~nm})$ and C) $\mathrm{FeCl}_{3}$ reagent. 
in a very huge spot at $\mathrm{R}_{\mathrm{f}}=0.68$. In comparison to that, from the four spots developed for the crude ASP extract, two spots with $R_{f}=0.66$ and $R_{f}=0.7$ were very close to gallic acid spots, and they were probably pyrogallic acid, a derivative of gallic acid which was later identified in LC-MS chromatogram of ASP crude extract and F1ASP. Pyrogallic acid is a compound that can be derived from gallic acid via decarboxylation reaction. ${ }^{35}$ Based on these TLC profiles, a combination of ethyl acetate and methanol were selected as the binary solvent system for fractionation of ASP using column chromatography.

When the sample was loaded with the starting solvent system $(25 \mathrm{ml}$ of $100 \%$ ethyl acetate), three different colours of bands of brown, green, and yellow started to appear. The first ( $25 \mathrm{ml}$ of $100 \%$ ethyl acetate) and the second ratio solvent system $(50 \mathrm{ml}$ of $70 \%$ ethyl acetate and $30 \%$ methanol mixture) allowed the bands to separate. However, the brown and green bands were strongly attracted to the silica column even though the third ratio solvent system $(50 \mathrm{ml}$ of $50 \%$ ethyl acetate and $50 \%$ methanol mixture) has been added. The strong attraction was most probably due to the strong polarity of compounds. For the third ratio, the yellow band started to elute and fractions started to be collected in a fixed volume-dependent manner. ${ }^{36}$ Altogether, a total of nine pale-yellowish fractions were collected; F1 and F2 were eluents collected when the ratio of solvent system used was ethyl acetate: methanol (5:5); F3, F4, and F5 were eluents collected when the ratio of solvent system used was ethyl acetate: methanol (3:7); F6, F7, and F8 were eluents collected when the ratio of the solvent system was 100 $\%$ methanol; while F9 was an eluent collected by washing the column again with $100 \%$ methanol. The yield of each fraction was shown in Table 1.
F9 has the highest yield ( $2.57 \mathrm{~g})$ while F1 has the lowest yield ( $0.34 \mathrm{~g})$ after being dried in an incubator. When F1 until F9 were spotted on TLC with a solvent system of ethyl acetate: methanol (9.5:0.5) with a drop of formic acid, numerous spots developed with different $R_{f}$ values when visualized using UV $254 \mathrm{~nm}$ (short wave), UV $365 \mathrm{~nm}$ (long wave), $\mathrm{FeCl}_{3}$ reagent, $50 \%$ sulphuric acid, and vanillin-sulphuric acid as shown in Figure 2. The summary of the spots developed on TLC profiles of F1 to F9 under different visualization agents was indicated in Table 2.

Fractions with the same spots developed (similar $\mathrm{R}_{\mathrm{f}}$ value) during TLC analysis were pooled as one fraction. F1, F2, F3, and F4 were pooled as F1ASP since they shared a similar spot of S5 and have few more spots such as S1, S4, S6, and S7 while at the same time, there were some spots which were only visualized by vanillin reagent. The subsequent fractions of F5, F6, F7, and F8 have two similar spots of S2 and S5 and thus, they were pooled as F2ASP. The final fraction, F9 was designated as F3ASP as only one single spot of S5 with an $R_{f}$ of $0.50 \pm 0.04 \mathrm{~cm}$ was present. Spot 55 which was also identified in the TLC of ASP was suggested as 1-galloyl-glucose, a compound which was found in LCMS chromatogram of ASP crude extract and all fractions. 1-galloylglucose can be produced by esterification of UDP-glucose and gallic acid, the first step of hydrolysable tannin biosynthesis in biosynthetic shikimic acid pathway. ${ }^{37}$ However, identification using preparative TLC and high-performance liquid chromatography analysis is required for further confirmation. The reference compound (gallic acid) appeared as a spot with an $R_{f}$ value of $0.68 \pm 0.03 \mathrm{~cm}$. There was no such spot with the same $R_{\mathrm{f}}$ value as gallic acid observed in the TLC of any fractions. The closest ones were $S 6$ with an $R_{f}$ value of $0.64 \pm 0.03 \mathrm{~cm}$ and $S 7$ with

Table 1: Yield of fractions derived from ASP crude extract.

\begin{tabular}{|c|c|c|c|c|c|c|c|c|c|c|c|}
\hline $\begin{array}{c}\text { Solvents } \\
\text { (Gradient elution) }\end{array}$ & $\begin{array}{l}\text { Ethyl acetate } \\
\text { (100\%) }\end{array}$ & $\begin{array}{l}\text { Ethyl acetate: } \\
\text { methanol } \\
(7: 3)\end{array}$ & \multicolumn{2}{|c|}{$\begin{array}{l}\text { Ethyl acetate: } \\
\text { methanol } \\
(5: 5)\end{array}$} & \multicolumn{3}{|c|}{$\begin{array}{l}\text { Ethyl acetate: methanol } \\
\qquad(3: 7)\end{array}$} & \multicolumn{3}{|c|}{$\begin{array}{l}\text { Methanol } \\
(100 \%)\end{array}$} & $\begin{array}{l}\text { Methanol } \\
\text { (Wash) } \\
(100 \%)\end{array}$ \\
\hline $\begin{array}{l}\text { Volume of binary solvent } \\
(\mathrm{ml})\end{array}$ & 25 & 50 & \multicolumn{2}{|c|}{50} & \multicolumn{3}{|c|}{50} & \multicolumn{3}{|c|}{50} & 100 \\
\hline $\begin{array}{c}\text { Fractions (Weight in } \\
\text { grams) }\end{array}$ & - & - & $\begin{array}{c}\text { F1 } \\
(0.34) \\
\llcorner\end{array}$ & $\begin{array}{c}\text { F2 } \\
(0.84)\end{array}$ & $\begin{array}{c}\text { F3 } \\
(0.48)\end{array}$ & $\begin{array}{c}\text { F4 } \\
(0.45) \\
\end{array}$ & $\begin{array}{c}\text { F5 } \\
(0.76) \\
\perp\end{array}$ & $\begin{array}{c} \\
\text { F6 } \\
(0.64)\end{array}$ & $\begin{array}{c} \\
\text { F7 } \\
(0.88)\end{array}$ & $\begin{array}{c}\mathbf{F 8} \\
(0.52) \\
\quad\end{array}$ & $\begin{array}{c}\text { F9 } \\
(2.57)\end{array}$ \\
\hline $\begin{array}{l}\text { New fractions after } \\
\text { pooling }\end{array}$ & - & - & \multicolumn{5}{|c|}{$\begin{array}{c}\text { Fraction 1 } \\
\text { (F1ASP) } \\
(2.11 \mathrm{~g})\end{array}$} & \multicolumn{3}{|c|}{$\begin{array}{c}\text { Fraction 2 } \\
\text { (F2ASP) } \\
(2.80 \mathrm{~g})\end{array}$} & $\begin{array}{c}\text { Fraction 3 } \\
\text { (F3ASP) }(2.57 \mathrm{~g})\end{array}$ \\
\hline Percentage yield (\%) & - & - & \multicolumn{5}{|c|}{$7.03 \%$} & \multicolumn{3}{|c|}{$9.33 \%$} & $8.57 \%$ \\
\hline
\end{tabular}

Table 2: Summary of the spots developed on TLC profiles of F1 to F9 and reference (standard) gallic acid under different visualization agents.

\begin{tabular}{|c|c|c|c|c|c|c|c|c|c|}
\hline $\begin{array}{l}\text { Visualization } \\
\text { methods/ } \\
\text { reagents }\end{array}$ & Description & $\begin{array}{c}S 1 \\
\left(R_{f}=\right. \\
0.20 \pm 0.01 \\
\mathrm{~cm})\end{array}$ & $\begin{array}{c}S 2 \\
\left(R_{f}=\right. \\
0.10 \pm 0.02 \\
\mathrm{~cm})\end{array}$ & $\begin{array}{c}S 3 \\
\left(R_{f}=0.30 \pm\right. \\
0.01 \mathrm{~cm})\end{array}$ & $\begin{array}{c}S 4 \\
\left(R_{f}=0.31 \pm\right. \\
0.02 \mathrm{~cm})\end{array}$ & $\begin{array}{c}S 5 \\
\left(R_{f}=0.50 \pm\right. \\
0.04 \mathrm{~cm})\end{array}$ & $\begin{array}{c}S 6 \\
\left(R_{f}=\right. \\
0.64 \pm 0.03 \\
\mathrm{~cm})\end{array}$ & $\begin{array}{c}S 7 \\
\left(R_{f}=0.76 \pm\right. \\
0.03 \mathrm{~cm})\end{array}$ & $\begin{array}{c}\text { Gallic acid } \\
\left(R_{\mathrm{f}}=0.68 \pm\right. \\
0.03 \mathrm{~cm})\end{array}$ \\
\hline UV 254 & $\begin{array}{l}\text { Visualization of the } \\
\text { quenched organic } \\
\text { compounds including } \\
\text { aromatic and conjugated } \\
\text { double bonds. }\end{array}$ & $\sqrt{ }$ & $\sqrt{ }$ & $\sqrt{ }$ & $\sqrt{ }$ & $\sqrt{ }$ & $\sqrt{ }$ & $\sqrt{ }$ & $\sqrt{ }$ \\
\hline UV 365 & $\begin{array}{l}\text { Visualization of most } \\
\text { polycyclic compounds. }\end{array}$ & $\sqrt{ }$ & $\sqrt{ }$ & & $\sqrt{ }$ & $\sqrt{ }$ & & & $\sqrt{ }$ \\
\hline $\mathrm{FeCl}_{3}$ reagent & $\begin{array}{l}\text { General detection on } \\
\text { phenolic compounds. }\end{array}$ & $\sqrt{ }$ & $\sqrt{ }$ & & $\sqrt{ }$ & $\sqrt{ }$ & $\sqrt{ }$ & & $\sqrt{ }$ \\
\hline $50 \%$ sulphuric acid & $\begin{array}{c}\text { General detection on } \\
\text { steroids. }\end{array}$ & $\sqrt{ }$ & & & $\sqrt{ }$ & & $\sqrt{ }$ & & \\
\hline $\begin{array}{l}\text { Vanillin-sulphuric } \\
\text { acid }\end{array}$ & $\begin{array}{l}\text { General detection on higher } \\
\text { alcohol, aldehydes, and } \\
\text { ketones. }\end{array}$ & $\sqrt{ }$ & & & $\sqrt{ }$ & & $\sqrt{ }$ & & \\
\hline
\end{tabular}




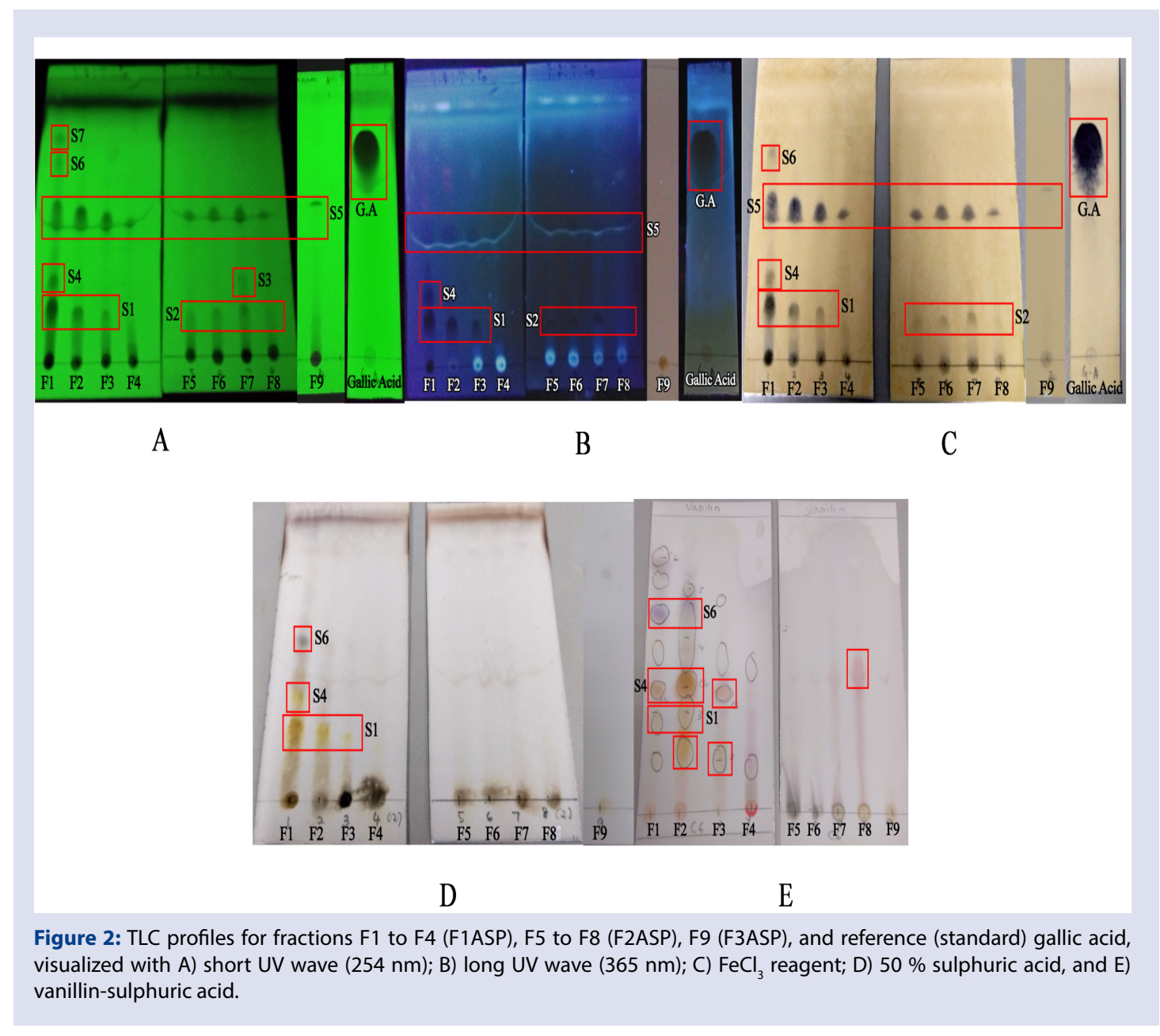

an $R_{f}$ value of $0.76 \pm 0.03 \mathrm{~cm}$. After pooling, F2ASP gave the highest yield of $2.80 \mathrm{~g}$ while F1ASP gave the lowest yield of $2.11 \mathrm{~g}$ (Table 1).

\section{Antihypertensive effects of S. polyanthum leaves crude extracts and fractions}

Three blood pressure parameters were measured in this study which includes mean arterial pressure (MAP), systolic blood pressure (SBP), and diastolic blood pressure (DBP). MAP is the average arterial pressure throughout one cardiac cycle and it is usually influenced by cardiac output and systemic vascular resistance. ${ }^{38} \mathrm{SBP}$ is the pressure measured during systole or heart contraction, while DBP is a pressure during diastole or relaxation period. While MAP is a better indicator of perfusion to vital organs than systolic blood pressure (SBP), SBP is a bigger risk factor than DBP for cardiovascular disease in elderly patients. ${ }^{39}$ Considering the individual importance of each parameter, this study includes all these three blood pressure parameters.

Figure 3 shows dose-response curves for MAP, SBP, and DBP of SHR when administered with HSP, ESP, MSP, and ASP crude extracts. The mean baselines for MAP, SBP, and DBP $(n=20)$ before intravenous administration of these crude extracts were $185.77 \pm 5.05 \mathrm{mmHg}$, $218.41 \pm 5.86 \mathrm{mmHg}$, and $157.04 \pm 5.27 \mathrm{mmHg}$, respectively. The negative control (vehicle that dissolved the extracts) did not give any significant changes to the baseline of all blood pressure parameters ( $\mathrm{n}$ $=5)$.

ASP crude extract caused significant reductions in MAP at $40 \mathrm{mg} /$ $\mathrm{kg}$ and $70 \mathrm{mg} / \mathrm{kg}$ by $35.07 \pm 3.80 \%(\mathrm{P}<0.001)$ and $67.82 \pm 8.44 \%$ $(\mathrm{P}<0.001)$, respectively (Figure $3 \mathrm{~A})$. The maximum reduction in MAP was observed at dose $70 \mathrm{mg} / \mathrm{kg}$ ASP crude extract. Meanwhile, MSP crude extract also caused significant reduction in MAP at $40 \mathrm{mg} / \mathrm{kg}$ and $70 \mathrm{mg} / \mathrm{kg}$ by $15.66 \pm 1.51 \%(\mathrm{P}<0.001)$ and $20.12 \pm 1.19 \%(\mathrm{P}<0.001)$, respectively. ESP crude extract only caused a significant reduction in MAP only at the highest dose of $70 \mathrm{mg} / \mathrm{kg}$ by $15.39 \pm 3.58 \%$. On the other hand, there was no significant reduction of MAP for HSP crude extract.

There were also significant reductions in SBP by ASP crude extract at 10 $\mathrm{mg} / \mathrm{kg}, 40 \mathrm{mg} / \mathrm{kg}$ and $70 \mathrm{mg} / \mathrm{kg}$ by $21.97 \pm 3.79 \%(\mathrm{P}<0.05), 35.76 \pm 4.74$ $\%(\mathrm{P}<0.001)$ and $73.75 \pm 6.93 \%(\mathrm{P}<0.001)$, respectively (Figure $3 \mathrm{~B})$. On the other hand, MSP crude extract caused a significant reduction in $\mathrm{SBP}$ at $40 \mathrm{mg} / \mathrm{kg}$ and $70 \mathrm{mg} / \mathrm{kg}$ by $20.58 \pm 1.50 \%(\mathrm{P}<0.001)$ and $16.19 \pm$ $1.80 \%(\mathrm{P}<0.001)$, respectively. Similar to reductions in MAP, ESP crude extract only caused a significant reduction in SBP of SHR only at the highest dose of $70 \mathrm{mg} / \mathrm{kg}$ by $16.51 \pm 3.82 \%(\mathrm{P}<0.001)$ while HSP gave no significant reduction in SBP at all.

Meanwhile for DBP, both ASP and MSP crude extracts gave significant reductions in DBP at $40 \mathrm{mg} / \mathrm{kg}$ and $70 \mathrm{mg} / \mathrm{kg}$. ASP significantly reduced DBP by $37.31 \pm 4.21 \%(\mathrm{P}<0.001)$ at $40 \mathrm{mg} / \mathrm{kg}$ and by $72.94 \pm 7.76 \%$ $(\mathrm{P}<0.001)$ at $70 \mathrm{mg} / \mathrm{kg}$ (Figure $3 \mathrm{C}$ ). While for MSP, it significantly reduced DBP by $17.79 \pm 2.24 \%(\mathrm{P}<0.001)$ at $40 \mathrm{mg} / \mathrm{kg}$ and by 21.84 $\pm 1.23 \%(\mathrm{P}<0.001)$ at $70 \mathrm{mg} / \mathrm{kg}$. ESP crude extract could only give a significant reduction $(\mathrm{P}<0.01)$ at $70 \mathrm{mg} / \mathrm{kg}$ by $15.39 \pm 3.58 \%$. However, there was no significant difference observed in DBP when administered with HSP crude extract at all dosages.

From the pattern of dose-response curves in Figure 3, HSP crude extract did not exhibit any significant antihypertensive effect and since it only extracted non-polar compounds, this has suggested that non-polar compounds did not significantly contribute to the antihypertensive 


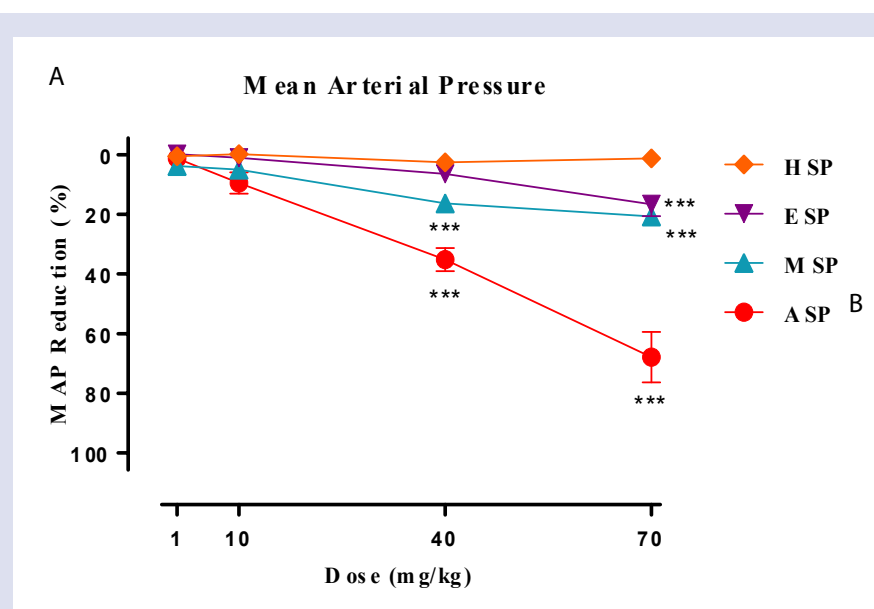

B

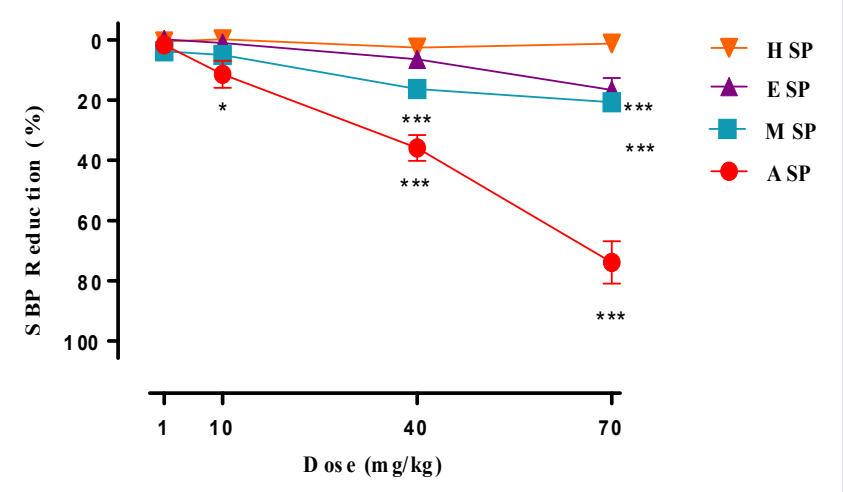

C

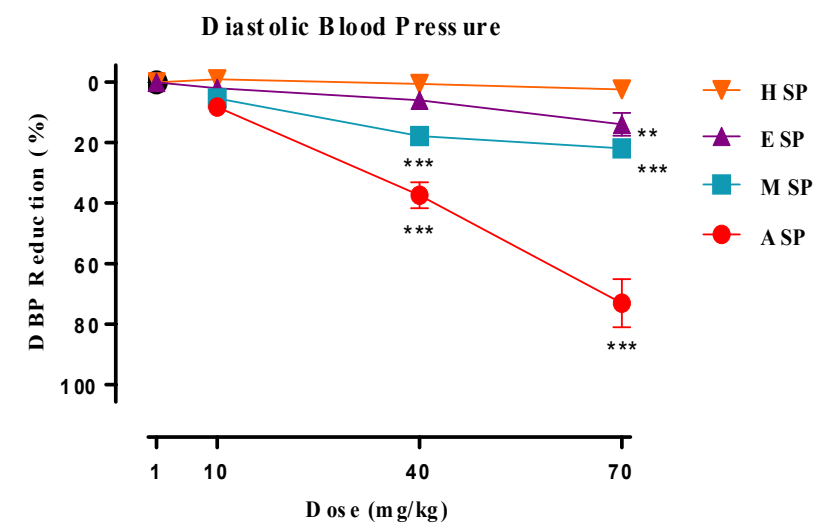

Figure 3: Dose-response curves for A) mean arterial pressure, B) systolic blood pressure, and C) diastolic blood pressure of Spontaneously Hypertensive Rats $(n=5)$ when intravenously administered with $n$-hexane (HSP), ethyl acetate (ESP), methanol (MSP), and aqueous (ASP) crude extracts at 1, 10, 40 and $70 \mathrm{mg} / \mathrm{kg}$. ${ }^{*}<0.05,{ }^{* *} \mathrm{P}<0.01$ and ${ }^{* * *} \mathrm{P}<0.001$, all vs. negative control $(0.90 \%$ normal saline) by using two-way ANOVA with post-hoc Sidak multiple comparison test.

effect for S. polyanthum leaves. On the other hand, it was observed that ASP crude extract has the most prominent antihypertensive effect as it caused more reduction in all blood pressure parameters, especially at dosages of $40 \mathrm{mg} / \mathrm{kg}$ and $70 \mathrm{mg} / \mathrm{kg}$ when compared to other crude extracts. In summary, though ESP and MSP have significantly reduced the blood pressure of SHR, the antihypertensive effects by these two extracts were not as prominent as ASP. Besides the fact that ASP showed the most prominent antihypertensive effect, aqueous extraction is usually advantageous from the pharmacological point of view. Aqueous extract usually is the safest solvent with less toxicity for animal study ${ }^{40}$, and at the same time it is cost-effective and is usually used to mimics the traditional preparation..$^{30}$ Considering all these findings, ASP was further fractionated in the subsequent study.

The subsequent antihypertensive study was conducted to identify the most active fraction. By using the same blood pressure parameters, the effect of fractions (F1ASP, F2ASP, F3ASP) was evaluated and compared with the original crude ASP extract. Normal saline $(0.90 \%)$ was used as the negative control while captopril $(5 \mathrm{mg} / \mathrm{kg}$ ) was used as the positive control. Figure 4 shows the magnitude of changes in MAP, SBP, and DBP when administered with the three fractions, in comparison with those exhibited by negative and positive controls as well as with the original ASP crude extract.

The mean baselines for MAP, SBP, and DBP $(n=20)$ of SHR in this experiment were $171.19 \pm 4.54 \mathrm{mmHg}, 198.71 \pm 4.09 \mathrm{mmHg}$, and
$144.51 \pm 3.94 \mathrm{mmHg}$, respectively. As shown in Figure 4A, there was no significant reduction observed on MAP of SHR with normal saline. Crude ASP extract at doses of 30,40,50, and $60 \mathrm{mg} / \mathrm{kg}$ significantly reduced MAP of SHR by $23.30 \pm 1.08 \%(\mathrm{P}<0.01), 32.85 \pm 3.75 \%$ $(\mathrm{P}<0.001), 25.78 \pm 7.09 \%(\mathrm{P}<0.01)$, and $29.24 \pm 9.10 \%(\mathrm{P}<0.01)$, respectively. Meanwhile for the fractions, F1ASP at doses of 30, 40, 50, and $60 \mathrm{mg} / \mathrm{kg}$ significantly reduced MAP by $25.41 \pm 3.57 \%(\mathrm{P}<0.01)$, $32.05 \pm 6.66 \%(\mathrm{P}<0.001), 25.46 \pm 4.55 \%(\mathrm{P}<0.05)$, and $27.39 \pm 2.42 \%$ $(\mathrm{P}<0.001)$, respectively. F2ASP at dosages of $20,30,40,50$, and $60 \mathrm{mg} /$ $\mathrm{kg}$ significantly reduced MAP by $30.87 \pm 6.70 \%(\mathrm{P}<0.001), 37.94 \pm$ $5.84 \%(\mathrm{P}<0.001), 36.66 \pm 5.41 \%(\mathrm{P}<0.001), 35.45 \pm 0.93 \%(\mathrm{P}<0.001)$, and $27.65 \pm 9.98 \%(\mathrm{P}<0.001)$, respectively. Nevertheless, for F3ASP, the MAP was significantly reduced only at two doses of 30 and $40 \mathrm{mg} / \mathrm{kg}$ by $25.64 \pm 5.67 \%(\mathrm{P}<0.001)$ and $33.70 \pm 5.45 \%(\mathrm{P}<0.001)$, respectively. In addition, $5 \mathrm{mg} / \mathrm{kg}$ of captopril (positive control) has significantly reduced MAP by $29.29 \pm 3.18 \%(\mathrm{P}<0.001$, Figure $4 \mathrm{~A})$. In comparison to positive control, the significant reduction in MAP by ASP $(30,40,50$ and $60 \mathrm{mg} / \mathrm{kg})$, F1ASP $(30,40,50$, and $60 \mathrm{mg} / \mathrm{kg})$, F2ASP $(20,30,40$, 50 , and $60 \mathrm{mg} / \mathrm{kg}$ ), and F3ASP (30 and $40 \mathrm{mg} / \mathrm{kg}$ ) was not significantly different with the reduction by captopril at $5 \mathrm{mg} / \mathrm{kg}$. This finding has indicated a comparable reduction in MAP between the positive control with ASP and the fractions at these dosages.

Meanwhile for SBP, ASP crude extract at dosages of 30, 40 and $50 \mathrm{mg} /$ kg significantly reduced SBP by $27.16 \pm 3.02 \%(\mathrm{P}<0.01), 32.80 \pm 3.55$ $\%(\mathrm{P}<0.001)$, and $26.19 \pm 13.52 \%(\mathrm{P}<0.01)$, respectively (Figure $4 \mathrm{~B})$. 


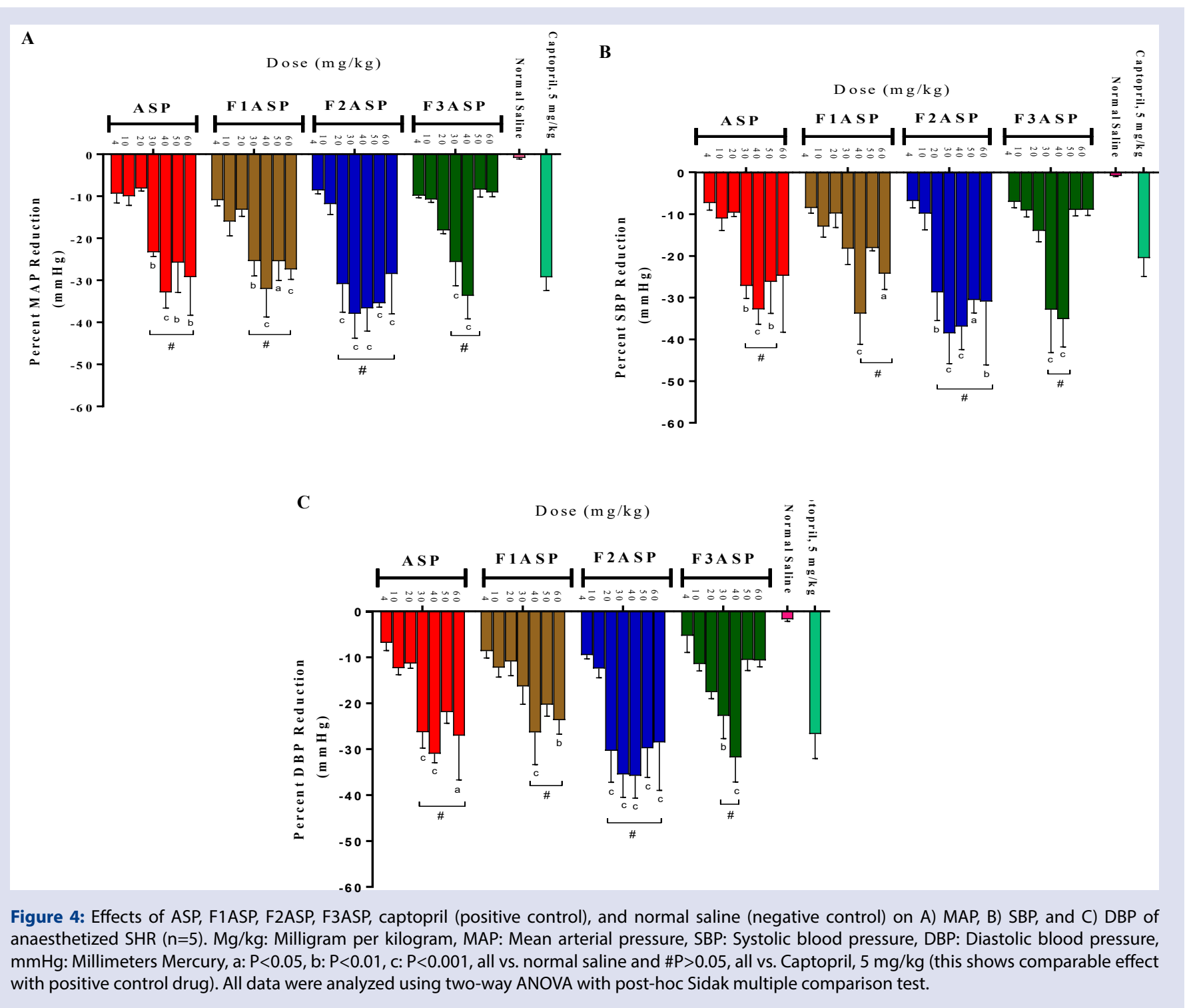

For the fractions, F1ASP only significantly reduced SBP at two dosages of 40 and $60 \mathrm{mg} / \mathrm{kg}$ by $33.79 \pm 7.35 \%(\mathrm{P}<0.001)$ and $24.25 \pm 3.78 \%$ $(\mathrm{P}<0.05)$, respectively. Meanwhile F2ASP at dosages of $20,30,40,50$, and $60 \mathrm{mg} / \mathrm{kg}$ significantly reduced SBP by $28.72 \pm 6.78 \%(\mathrm{P}<0.01)$, $38.54 \pm 7.26 \%(\mathrm{P}<0.001), 36.92 \pm 5.53 \%(\mathrm{P}<0.001), 30.56 \pm 3.08 \%$ $(\mathrm{P}<0.05)$, and $30.93 \pm 15.17 \%(\mathrm{P}<0.01)$, respectively. With the similar pattern observed for MAP changes, the SBP was significantly reduced by F3ASP only at two dosages of 30 and $40 \mathrm{mg} / \mathrm{kg}$ by $32.87 \pm 10.32 \%$ $(\mathrm{P}<0.001)$ and $35.11 \pm 6.69 \%(\mathrm{P}<0.001)$, respectively. The significant reductions in SBP by ASP $(30,40,50$ and 60$), \mathrm{F} 1 \mathrm{ASP}(30,40,50$, and $60 \mathrm{mg} / \mathrm{kg}$ ), F2ASP $(20,30,40,50$, and $60 \mathrm{mg} / \mathrm{kg}$ ), and F3ASP (30 and $40 \mathrm{mg} / \mathrm{kg}$ ) for all dosages were not significantly different than the reduction by positive control (captopril) at $5 \mathrm{mg} / \mathrm{kg}$ (Figure $4 \mathrm{~B}$ ). These findings showed a comparable reduction in SBP of SHR by the positive control with ASP and the fractions at these dosages.

As illustrated in Figure 4C, ASP at doses of 30, 40, and $60 \mathrm{mg} / \mathrm{kg}$ significantly reduced DBP by $26.30 \pm 3.45 \%(\mathrm{P}<0.001), 35.08 \pm$ $4.37 \%(\mathrm{P}<0.001)$, and $27.04 \pm 9.65 \%(\mathrm{P}<0.05)$, respectively. For the fractions, only two dosages of F1ASP at 40 and $60 \mathrm{mg} / \mathrm{kg}$ significantly reduced $\mathrm{DBP}$ by $26.36 \pm 6.99 \%(\mathrm{P}<0.001)$ and $23.67 \pm 3.06 \%$ $(\mathrm{P}<0.01)$, respectively. F2ASP at dosages of $20,30,40,50$, and $60 \mathrm{mg} /$ $\mathrm{kg}$ significantly reduced $\mathrm{DBP}$ by $30.37 \pm 6.83 \%(\mathrm{P}<0.001), 35.48 \pm 5.01$
$\%(\mathrm{P}<0.001), 35.81 \pm 4.86 \%(\mathrm{P}<0.001), 29.78 \pm 6.343 \%(\mathrm{P}<0.01)$, and $28.52 \pm 10.48 \%(\mathrm{P}<0.001)$, respectively. In spite of that, for F3ASP, DBP was also significantly reduced only at two doses of 30 and $40 \mathrm{mg} / \mathrm{kg}$ by $22.73 \pm 4.98 \%(\mathrm{P}<0.01)$, and $31.80 \pm 5.33 \%(\mathrm{P}<0.001)$, respectively. Five $\mathrm{mg} / \mathrm{kg}$ of captopril (positive control) significantly reduced DBP by $28.52 \pm 10.48 \%(\mathrm{P}<0.001)$ (Figure $4 \mathrm{C})$. These significant reductions in DBP by ASP (30, 40, 50, and $60 \mathrm{mg} / \mathrm{kg})$, F1ASP $(40,50$, and $60 \mathrm{mg} / \mathrm{kg})$, F2ASP $(20,30,40,50$, and $60 \mathrm{mg} / \mathrm{kg}$ ), and F3ASP (30 and $40 \mathrm{mg} / \mathrm{kg}$ ) were not significantly different than the reduction by captopril $(5 \mathrm{mg} /$ $\mathrm{kg}$ ). This finding has also indicated a comparable reduction in DBP by the positive control with ASP and the fractions at these dosages.

Dose-response curves for the effect of each fraction on MAP, SBP, and DBP were then constructed and then compared with ASP crude extract (Figure 5). Both ASP and F1ASP started to cause significant reductions in MAP, SBP, and DBP at $30 \mathrm{mg} / \mathrm{kg}$, then it caused a maximum reduction in MAP, SBP, and DBP at $40 \mathrm{mg} / \mathrm{kg}$, and then the curve has started to become plateau afterward. In contrast to ASP and F1ASP, F2ASP started to produce significant MAP, SBP and DBP reduction at a low dose of 20 $\mathrm{mg} / \mathrm{kg}$, and then the effect has become plateau from $30 \mathrm{mg} / \mathrm{kg}$ until 60 $\mathrm{mg} / \mathrm{kg}$. In fact, the maximum reduction in MAP by F2ASP at $30 \mathrm{mg} /$ $\mathrm{kg}$ was actually higher $(\mathrm{P}<0.05)$ than the other fractions and also ASP crude extract (Figure 5A). F3ASP showed the same trend as ASP and 


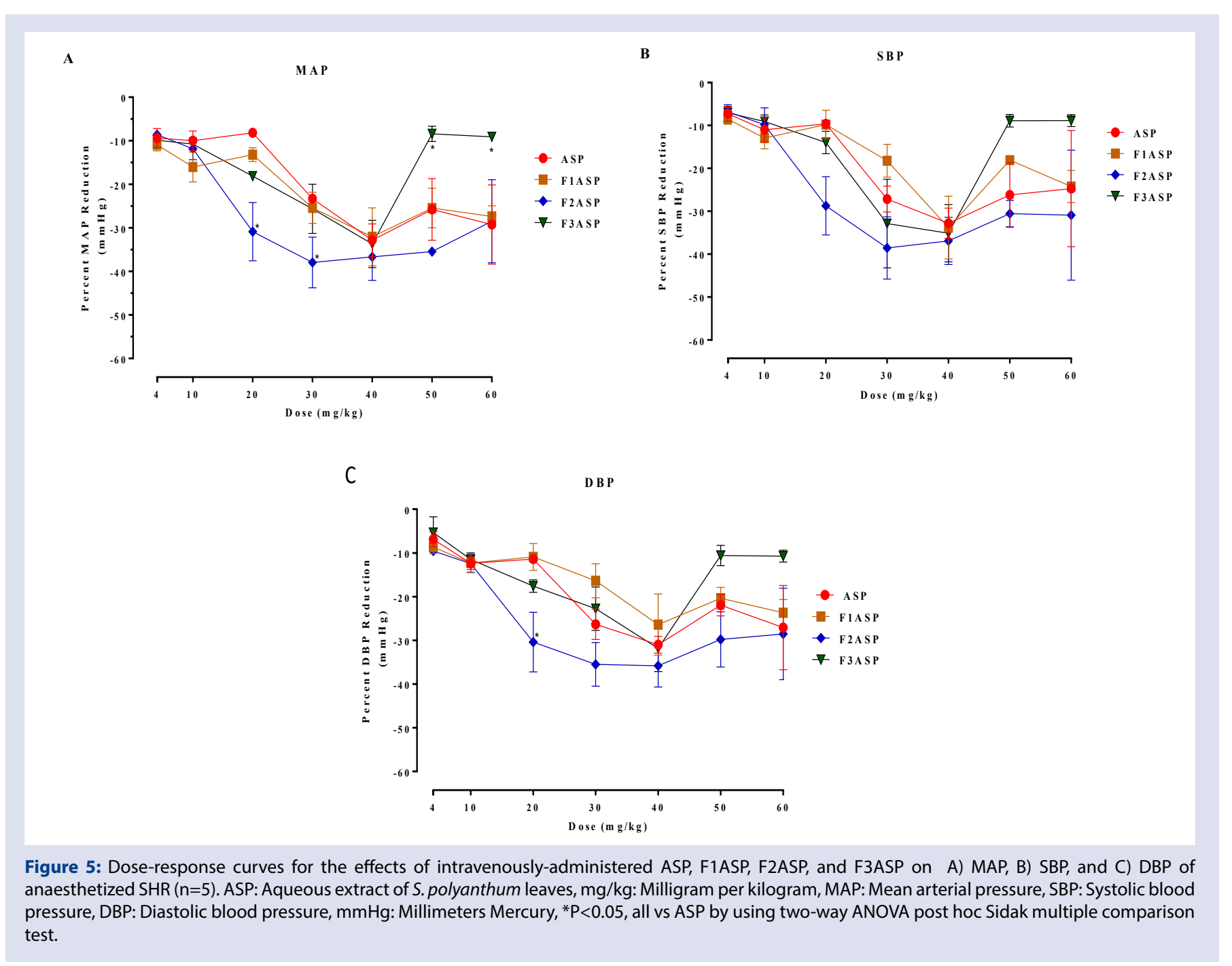

F1ASP at low dosages, and then the effects became reduced at $50 \mathrm{mg} /$ $\mathrm{kg}$ and maintained at $60 \mathrm{mg} / \mathrm{kg}$. It is postulated that for F3ASP, there are different receptors involved at low and high dosages. When the reduction in blood pressure has reached maximum through activating the first receptor, then at the higher dosages, the fraction might activate another receptor system that causes attenuation of the antihypertensive effect. The involvement of receptors can be further investigated through in-depth pharmacodynamics studies.

To analyze the potency of the ASP crude extract and fractions, their $\mathrm{ED}_{50}$ was then determined using $\mathrm{GraphPad}^{\oplus}$ Prism Version 6.00 software based on the constructed dose-response curves. $\mathrm{ED}_{50}$ is an effective dose that produces $50 \%$ of the maximal effect. The $\mathrm{ED}_{50}$ values for MAP, SBP and DBP reduction by F2ASP were $14.16 \mathrm{mg} / \mathrm{kg}, 19.17$ $\mathrm{mg} / \mathrm{kg}$ and $13.80 \mathrm{mg} / \mathrm{kg}$, respectively. These $\mathrm{ED}_{50}$ values were actually lower than the $\mathrm{ED}_{50}$ values for ASP crude extract $(29.48 \mathrm{mg} / \mathrm{kg}, 29.18$ $\mathrm{mg} / \mathrm{kg}$ and $23.53 \mathrm{mg} / \mathrm{kg}$, respectively) and F1ASP $(29.08 \mathrm{mg} / \mathrm{kg}, 30.00$ $\mathrm{mg} / \mathrm{kg}$ and $30.15 \mathrm{mg} / \mathrm{kg}$, respectively). On the other hand, F3ASP's pattern of reduction in blood pressure differed from the other fractions. After the antihypertensive effect by F3ASP reached maximum, then the effect was significantly reduced at subsequent dosages $(50 \mathrm{mg} / \mathrm{kg}$ and $60 \mathrm{mg} / \mathrm{kg}$ ). Thus, the $\mathrm{ED}_{50}$ value of F3ASP could not be determined in this study. Altogether, F2ASP was more potent as compared to ASP and F1ASP and thus was considered as the most active fraction. The high potency of F2ASP might be due to the high concentration of the bioactive compound in this fraction compared to its crude extract itself. In agreement, Idris et $a l^{41}$ also found a higher antihypertensive effect of the fraction compared to crude extract and suggested the probability of an increased concentration of active compounds during the partitioning process.

\section{Total phenolic content}

This study examined the total phenolic content of the crude ASP extract and the three derived fractions (F1ASP, F2ASP, and F3ASP) by using Folin-Ciocalteu assay. Folin-Ciocalteu assay was generally a modified method from analysis of protein and is widely used for determination of the total phenolic content of various plant extracts. ${ }^{25,26,42,43}$ This assay was chosen to be used in this study as it is commercially available and has a standard procedure. ${ }^{26}$ This assay utilizes Folin-Ciocalteau reagent that determine phenols and easily-oxidized substances by forming a blue color complex form, reducing the yellow color of heteroply phosphomolibdate-tungstate anions. ${ }^{25}$ The concentration of phenols can be determined by the blue color formed. However, this reaction's mechanism is not solely used for specific determination of only phenolics, instead, it can be used for determining any reducing compounds that can react with the phosphotungstic reagent. ${ }^{42}$

Figure 6 shows the standard curve of gallic acid with an $\mathrm{R}_{2}$ value of 0.992. The TPC for ASP, F1ASP, F2ASP, and F3ASP is shown in Table 3. ASP crude extract had the highest total phenolic content $(232.81$ $\pm 0.67 \mathrm{mg} \mathrm{GAE} / \mathrm{g})$, followed by F1ASP $(76.15 \pm 3.75 \mathrm{mg} \mathrm{GAE} / \mathrm{g})$, F3ASP $(36.45 \pm 1.35 \mathrm{mg} \mathrm{GAE} / \mathrm{g})$ and lastly F2ASP $(30.52 \pm 5.83 \mathrm{mg}$ GAE/g). TPCs for all fractions were significantly different $(\mathrm{P}<0.001)$ than ASP, in which all of them have lower TPC than ASP. The TPC 


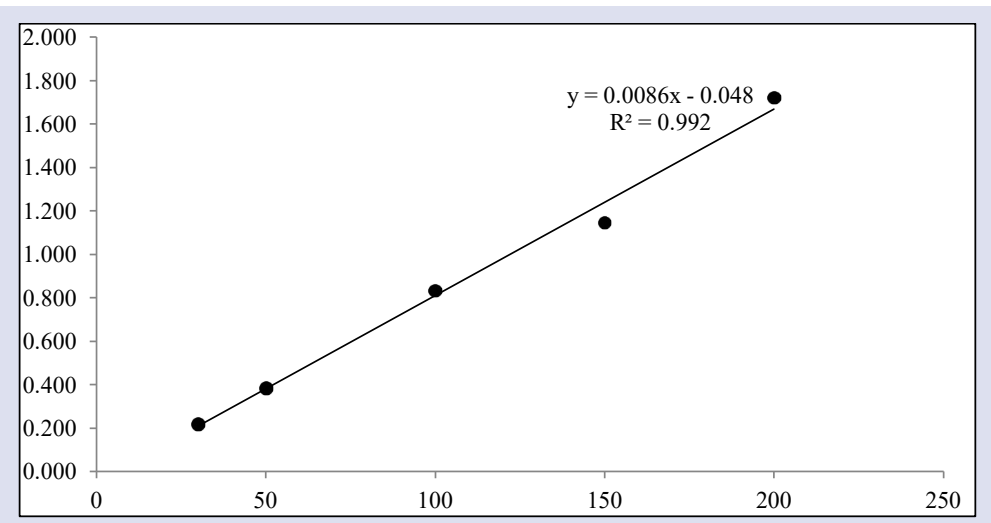

Figure 6: Standard curve of gallic acid which was used to determine the total phenolic content of ASP crude extract and fractions, expressed as $\mathrm{mg} / \mathrm{g}$ gallic acid equivalent (GAE).

Table 3: Total phenolic content of ASP crude extract and fractions.

\begin{tabular}{cccccc}
\hline \multirow{2}{*}{ No. } & \multirow{2}{*}{ Sample } & \multicolumn{2}{c}{ Total phenolic content (GAE mg/gram) } & \multirow{2}{*}{ Mean \pm SD } \\
\cline { 3 - 5 } & & Trial 1 & Trial 2 & Trial 3 & $76.15 \pm 3.75^{*+*}$ \\
2 & F1ASP & 78.60 & 71.83 & 78.012 & $30.52 \pm 5.83^{*+*}$ \\
3 & F2ASP & 25.01 & 36.63 & 29.907 & $36.45 \pm 1.35^{*+*}$ \\
4 & F3ASP & 38.01 & 35.67 & 35.674 & $232.81 \pm 0.67$ \\
\hline
\end{tabular}

Note. Symbol ${ }^{\star * \star}$ showing $\mathrm{P}<0.001$, all $v$ s ASP using one way ANOVA with post-hoc Sidak multiple comparison test.

of both F2ASP and F3ASP were not significantly different. Thus, the order of TPC of $S$. polyanthum leaves from the highest to the lowest order was ASP $>$ F1ASP $>$ F3ASP $=$ F2ASP. Since the reaction of Folin's reagent also based on a redox reaction, the TPC assay would detect all substances that were oxidized ${ }^{44}$, and this may include several potential reductants such as the reducing sugars glucose and fructose. This might cause significant effect on the accuracy of the TPC assay. ${ }^{43}$ Note that from LC-MS analyses, the ASP crude extract and all fractions contained a lot of glucosides (glucose bounded to another functional group) in which the glucose part may affect the reactions. Besides, this assay involves an oxidation reaction where the blue chromophore is formed by a phosphotungstic-phosphomolybdenum complex in which the maximum absorption depends on the alkaline solution and the concentration of phenolic compounds oxidized. ${ }^{25}$ Thus, the TPC assay would only detect phenolics that can function as reductants in a redoxlinked colorimetric method. In addition, less availability of hydroxyl group or non-oxidized phenolics could also contribute to the low concentration of phenolics and eventually affected the total phenolic content analyzed.

In comparison with previous studies on the TPC of $S$. polyanthum leaves, it was found that the TPC of water extract of $S$. polyanthum leaves collected in Singapore was $11.21 \mathrm{mg} \mathrm{GAE}^{44}$, a value which was lower than our present finding. Safriani et $a l^{45}$ also reported a lower TPC of water extract $(\approx 40.0 \mathrm{mg} \mathrm{GAE} / \mathrm{g})$ compared to the current findings. However, Har and Ismail ${ }^{46}$ found that the methanolic extract of $S$. polyanthum leaves contained $1,125 \mathrm{mg} \mathrm{GAE} / \mathrm{g}$, which indicated for higher TPC than our ASP crude extract (232.81 $\pm 0.67 \mathrm{mg} \mathrm{GAE} / \mathrm{g})$. The higher phenolic content of methanol extract compared to the water extract used in our current study was probably due to the higher efficiency of methanol in extracting polyphenol. Methanol actually causes cell wall degradation causing more polyphenols to be released from the cells. ${ }^{30}$

\section{Phenolic compounds identified using LC-QTOF/MS}

The different magnitude of antihypertensive effects by the extracts and the fractions may be affected by their varying phytochemical composition. Thus, LC-QTOF/MS analyses were then run for the most prominent crude extract, ASP, as well as for the three derived fractions (F1ASP, F2ASP, and F3ASP). Since this LC-QTOF/MS analysis was conducted in negative mode, only compounds with negative ions at high $\mathrm{pH}$ were detected. Figure 7 showed the LC-MS chromatograms of the blank (methanol) and ASP crude extract while Table 4 listed all the eluted compounds. In total, there were 216 peaks eluted out using the binary gradient elution with some redundant compounds detected as different peaks and at different retention times. Thus, in total, only 93 single compounds were actually detected in this analysis. In terms of composition, ASP crude extract was composed of gallotannins, phenolic acids, glucosides, flavonoids, and simple phenols. The highest intensity compound (highest percent response) was 2,4,7-trihydroxy-9, 10-dihydrophenanthrene which was eluted at $11.90 \mathrm{~min}$ with an intensity of $14.36 \%$. Another two highest intensity compounds were osmanthuside $\mathrm{H}(4.33 \%)$ and sinapaldehyde (3.56 \%). Meanwhile compound with the least intensity was 3, 4-dihydroxyphenothyl-3-O$\beta$-D-glucopyranoside by $0.06 \%$.

Figure 8 shows LC-MS chromatograms for the blank methanol and F1ASP while Table 5 listed all the eluted compounds. In total, there were 76 peaks eluted out using the binary gradient elution with some redundant compounds. To be exact, only 46 single compounds that were detected in this analysis. The highest intensity compound (highest percent response) was feroxin A at 5.76 min with an intensity of $8.44 \%$. Another two highest intensity compounds were 2,4,7-trihydrohydroxy9,10-dihydrophenanthrene (7.79\%) and 1-galloyl-glucose $(6.90 \%)$. Meanwhile, the compound with the least intensity was cyclocurcumin with an intensity of $0.38 \%$.

Figure 9 shows the LC-MS chromatogram for the blank methanol and F2ASP while Table 6 listed all the eluted compounds. There were 13 peaks present in the chromatogram with few compounds that occurred in redundancy. Thus, there were only six compounds to be exact in F2ASP. These phytochemical compounds were either gallotannins, simple phenols, or isoflavanoids. The highest intensity of compound (highest percent response) in F2ASP was 1-galloyl-glucose; it was eluted at $1.33 \mathrm{~min}$ with an intensity of $20.24 \%$. Another two highest 
Item name: blank methanol 02

Channel name: 2: HD TOF MSe (100-1000) -4eV ESI- (IIC)

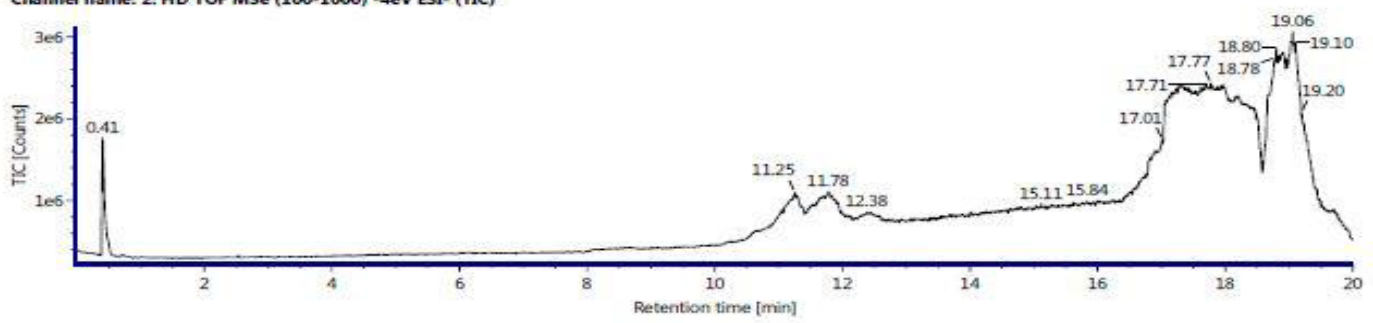

Item name: spolyanthum 02
Channel name: 2 : HD TOF MSe (100-1000) -4eV ESI- (TIC)

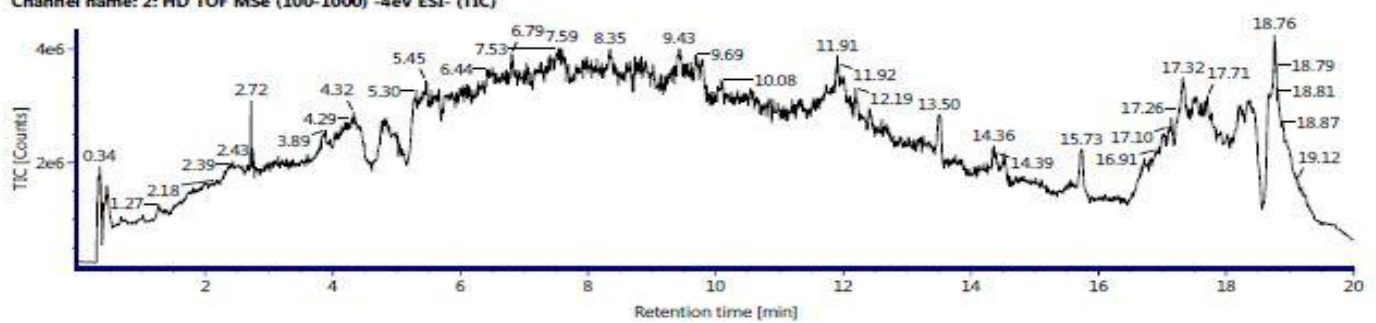

Figure 7: Chromatogram of blank methanol and crude ASP extract.

Item name: BLANK METHANOL O1

Channel name: 2: HD TOF MSe (100-1000) -4eV ESI- (IIC)

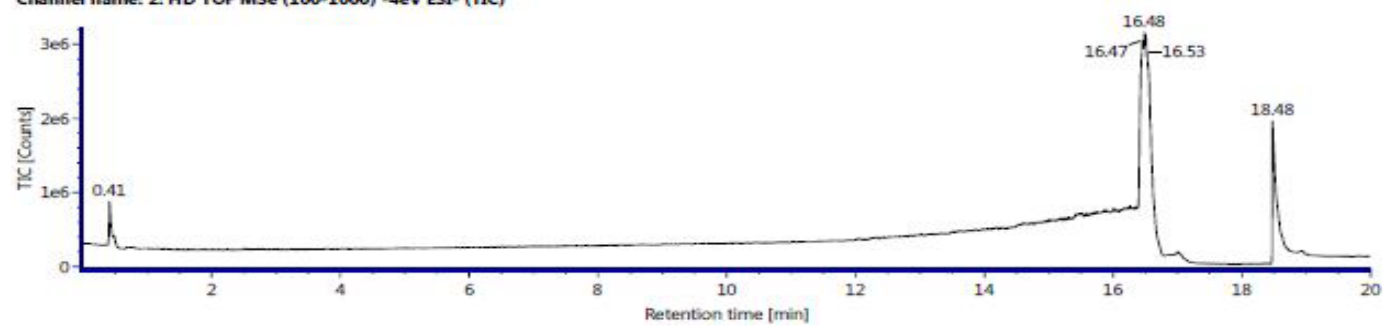

Item name: FASP1 01

Channel name: 2: HD TOF MSe (100-1000) -4eV ESI- (TIC)

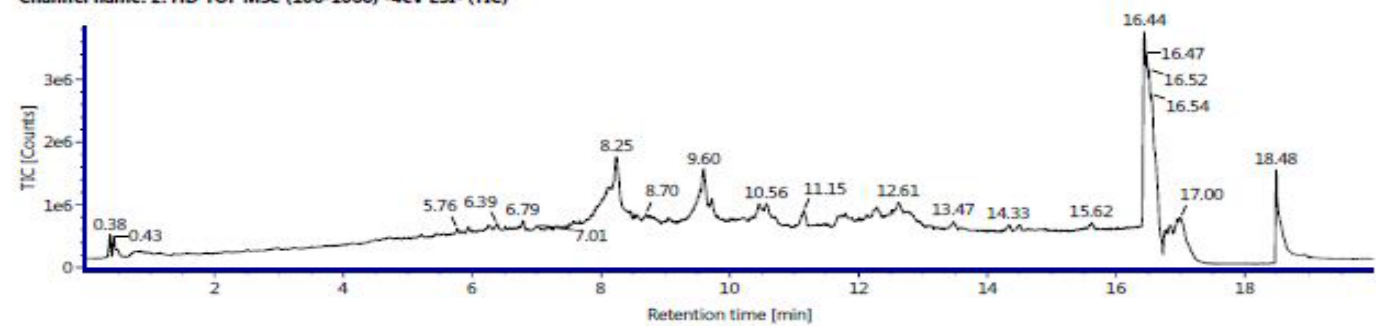

Figure 8: Chromatogram of blank methanol and F1ASP. 


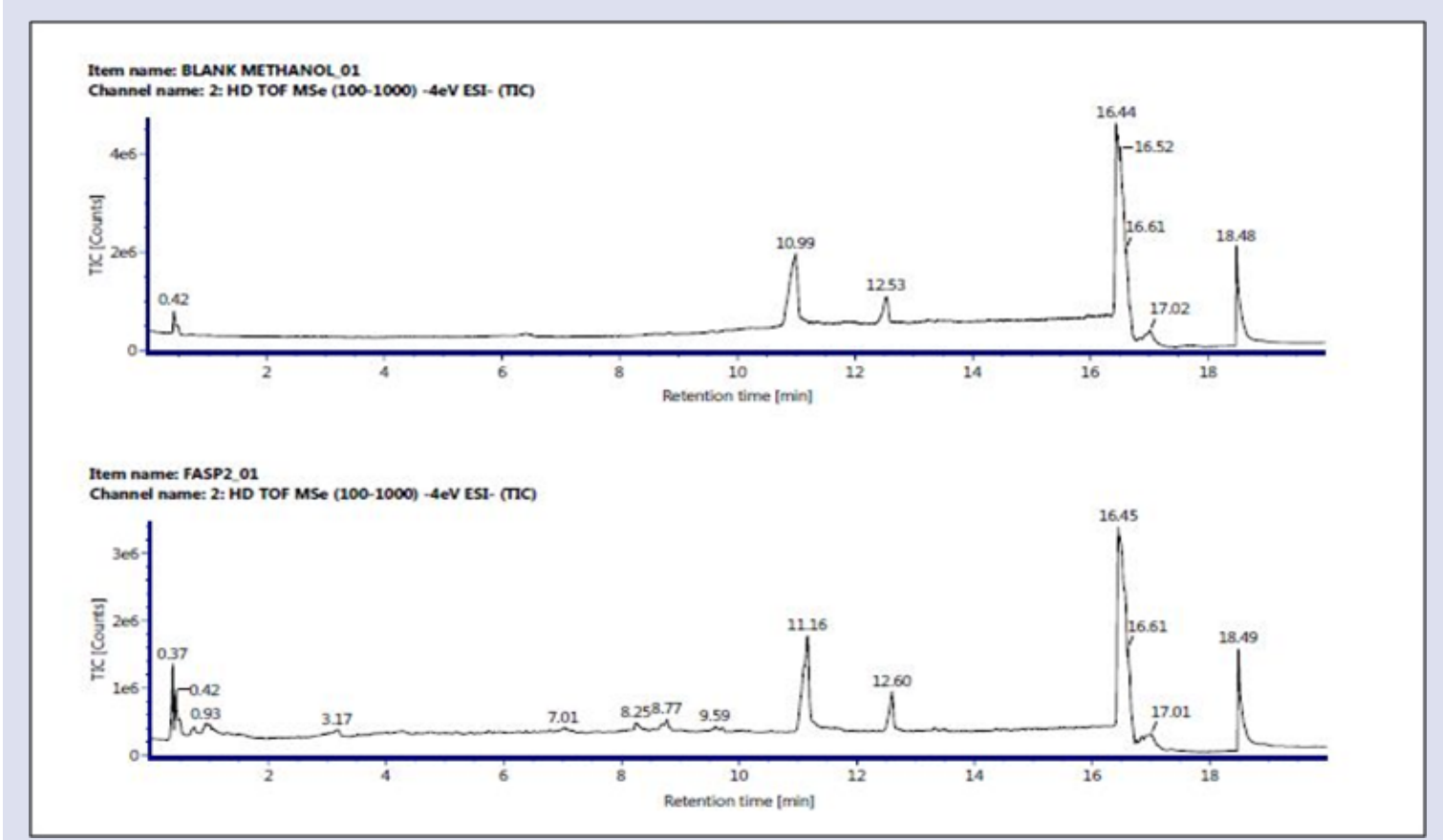

Figure 9: Chromatogram of blank methanol and F2ASP.

Table 4: Phytochemical compounds in ASP crude extract using LC-MS.

\begin{tabular}{|c|c|c|c|c|c|c|}
\hline No. & Compound & Molecular Formula & $\begin{array}{l}\text { RT } \\
(\min )\end{array}$ & Chemical Classes & Response \% & {$\left[\mathrm{M}^{+}\right]$} \\
\hline 1 & 1-Galloyl-glucose & $\mathrm{C}_{13} \mathrm{H}_{16} \mathrm{O}_{10}$ & 0.43 & Gallotannin & 0.15 & 331.07 \\
\hline 2 & Cassialactone & $\mathrm{C}_{16} \mathrm{H}_{16} \mathrm{O}_{6}$ & 0.44 & Simple phenol & 0.12 & 349.09 \\
\hline 3 & Pyrogallic acid & $\mathrm{C}_{6} \mathrm{H}_{6} \mathrm{O}_{3}$ & 0.53 & Phenolic acid derivative & 0.11 & 125.02 \\
\hline 4 & Pyrogallic acid & $\mathrm{C}_{6} \mathrm{H}_{6} \mathrm{O}_{3}$ & 0.79 & Phenolic acid derivative & 0.07 & 125.02 \\
\hline 5 & 1-Galloyl-glucose & $\mathrm{C}_{13} \mathrm{H}_{16} \mathrm{O}_{10}$ & 0.91 & Gallotannin & 0.35 & 331.07 \\
\hline 6 & 2,3-(S)-Hexahydroxydiphenol-D-glucose & $\mathrm{C}_{20} \mathrm{H}_{18} \mathrm{O}_{14}$ & 1.05 & Glucoside & 0.35 & 481.06 \\
\hline 7 & Pyrogallic acid & $\mathrm{C}_{6} \mathrm{H}_{6} \mathrm{O}_{3}$ & 1.19 & Phenolic acid derivative & 0.26 & 125.02 \\
\hline 8 & Cassialactone & $\mathrm{C}_{16} \mathrm{H}_{16} \mathrm{O}_{6}$ & 1.26 & Simple phenol & 0.10 & 349.09 \\
\hline 9 & Pyrogallic acid & $\mathrm{C}_{6} \mathrm{H}_{6} \mathrm{O}_{3}$ & 1.42 & Phenolic acid derivative & 0.07 & 125.02 \\
\hline 10 & Methyl- $\beta$-orsellinate & $\mathrm{C}_{9} \mathrm{H}_{10} \mathrm{O}_{4}$ & 1.53 & Ester phenol & 0.11 & 181.05 \\
\hline 11 & $\begin{array}{l}\text { 3,4-Dihydroxy phenothyl-3-O- } \beta \text {-D- } \\
\text { glucopyranoside }\end{array}$ & $\mathrm{C}_{12} \mathrm{H}_{16} \mathrm{O}_{8}$ & 2.01 & Glucoside & 0.06 & 333.08 \\
\hline 12 & $\begin{array}{l}\text { 2,4,5Trihydeoxy } \\
\text { benzaldehyde }\end{array}$ & $\mathrm{C}_{7} \mathrm{H}_{6} \mathrm{O}_{4}$ & 2.07 & Simple phenol & 0.11 & 153.02 \\
\hline 13 & Cassialactone & $\mathrm{C}_{16} \mathrm{H}_{16} \mathrm{O}_{6}$ & 2.19 & Simple phenol & 0.08 & 349.09 \\
\hline 14 & 1-Galloyl-glucose & $\mathrm{C} 13 \mathrm{H}_{16} \mathrm{O}_{10}$ & 2.24 & Gallotannin & 0.18 & 331.07 \\
\hline 15 & 1-Galloyl-glucose & $\mathrm{C}_{13} \mathrm{H}_{16} 6 \mathrm{O}_{10}$ & 2.31 & Gallotannin & 0.67 & 331.07 \\
\hline 16 & Caesalpins J & $\mathrm{C}_{17} \mathrm{H}_{16} \mathrm{O}_{6}$ & 2.96 & Simple phenol & 1.21 & 361.09 \\
\hline 17 & Osmanthuside $\mathrm{H}$ & $\mathrm{C}_{19} \mathrm{H}_{28} \mathrm{O}_{11}$ & 3.07 & Glycoside phenol & 0.92 & 431.16 \\
\hline 18 & Feroxin A & $\mathrm{C}_{17} \mathrm{H}_{24} \mathrm{O}_{8}$ & 3.26 & 3-O Glucoside & 0.19 & 401.14 \\
\hline 19 & 3'-O-Methylbrazilin & $\mathrm{C}_{17} \mathrm{H}_{16} \mathrm{O}_{5}$ & 3.36 & Simple phenol & 0.20 & 345.10 \\
\hline 20 & Feralolide & $\mathrm{C}_{18} \mathrm{H}_{16} \mathrm{O}_{7}$ & 3.42 & Dihydro-isocoumarin & 0.10 & 343.08 \\
\hline 21 & Darendoside A & $\mathrm{C}_{19} \mathrm{H}_{28} \mathrm{O}_{11}$ & 3.88 & $\begin{array}{l}\text { Phenethyl alcohol glyco- } \\
\text { sides }\end{array}$ & 2.99 & 431.16 \\
\hline 22 & Caesalpins J & $\mathrm{C}_{17} \mathrm{H}_{16} \mathrm{O}_{6}$ & 3.93 & Simple phenol & 1.18 & 361.09 \\
\hline 23 & Tachioside & $\mathrm{C}_{13} \mathrm{H}_{18} \mathrm{O}_{8}$ & 3.98 & Phenolic glycoside & 0.09 & 301.09 \\
\hline 24 & Tachioside & $\mathrm{C}_{13} \mathrm{H}_{18} \mathrm{O}_{8}$ & 3.98 & Phenolic glycoside & 0.11 & 301.09 \\
\hline 25 & Dendrocandin B & $\mathrm{C}_{27} \mathrm{H}_{30} \mathrm{O}_{8}$ & 4.05 & Bibenzyl phenols & 0.09 & 481.19 \\
\hline 26 & Osmanthuside $\mathrm{H}$ & $\mathrm{C}_{19} \mathrm{H}_{28} \mathrm{O}_{11}$ & 4.33 & Glycoside Phenols & 4.33 & 431.16 \\
\hline 27 & Odoriflavene & $\mathrm{C}_{17} \mathrm{H}_{16} \mathrm{O}_{5}$ & 4.36 & Isoflavene & 0.22 & 345.10 \\
\hline 28 & Sesamol & $\mathrm{C}_{7} \mathrm{H}_{6} \mathrm{O}_{3}$ & 4.40 & Hydroquinone derivative & 0.24 & 183.03 \\
\hline 29 & $2,4,4^{\prime}, 6^{\prime}$-Tetrahydroxy-benzophenone & $\mathrm{C}_{13} \mathrm{H}_{10} \mathrm{O}_{5}$ & 4.40 & Benzophenone & 0.22 & 245.05 \\
\hline
\end{tabular}




\begin{tabular}{|c|c|c|c|c|c|c|}
\hline 30 & Haematoxylin & $\mathrm{C}_{16} \mathrm{H}_{14} \mathrm{O}_{6}$ & 4.41 & Phenocyanin & 0.14 & 347.08 \\
\hline 31 & Feroxin A & $\mathrm{C}_{17} \mathrm{H}_{24} \mathrm{O}_{8}$ & 4.42 & 3-O Glucoside & 0.34 & 401.14 \\
\hline 32 & Caesalpins J & $\mathrm{C}_{17} \mathrm{H}_{16} \mathrm{O}_{6}$ & 4.49 & Simple phenol & 1.21 & 361.09 \\
\hline 33 & Cistanoside $\mathrm{H}$ & $\mathrm{C}_{22} \mathrm{H} 32 \mathrm{O}_{13}$ & 4.55 & Glucoside & 0.09 & 503.18 \\
\hline 34 & Polydatin & $\mathrm{C}_{20} \mathrm{H}_{22} \mathrm{O}_{8}$ & 4.58 & Glucoside & 0.29 & 435.13 \\
\hline 35 & Caesalpins J & $\mathrm{C}_{17} \mathrm{H}_{16} \mathrm{O}_{6}$ & 4.79 & Simple phenol & 0.10 & 361.09 \\
\hline 36 & $\begin{array}{l}\text { 10-O-Methyl } \\
\text { protosappanin B }\end{array}$ & $\mathrm{C}_{17} \mathrm{H}_{18} \mathrm{O}_{6}$ & 4.85 & Dibenzoxocin derivative & 0.08 & 363.11 \\
\hline 37 & Moracin F & $\mathrm{C}_{16} \mathrm{H}_{14} \mathrm{O}_{5}$ & 4.86 & 2-arylbenzofuran flavanoid & 0.15 & 285.08 \\
\hline 38 & $\begin{array}{l}2,3,5,4 \text { '- } \\
\text { Tetrahydroxystilbene-2,3-O- } \beta \text { - } \\
\text { Dglucopyranoside }\end{array}$ & $\mathrm{C}_{26} \mathrm{H}_{32} \mathrm{O}_{14}$ & 4.93 & Glucoside & 1.31 & 567.17 \\
\hline 39 & Methyl- $\beta$-orsellinate & $\mathrm{C}_{9} \mathrm{H}_{10} \mathrm{O}_{4}$ & 4.94 & Ester phenol & 0.20 & 227.06 \\
\hline 40 & Protosappanin C & $\mathrm{C}_{16} \mathrm{H}_{14} \mathrm{O}_{6}$ & 5.02 & Dibenzoxocin derivative & 0.07 & 347.08 \\
\hline 41 & 2,4,7-Trihydroxy-9,10-dihydrophenanthrene & $\mathrm{C}_{14} \mathrm{H}_{12} \mathrm{O}_{3}$ & 5.27 & Phenanthrene phenol & 0.50 & 273.08 \\
\hline 42 & Kakuol & $\mathrm{C}_{10} \mathrm{H}_{10} \mathrm{O}_{4}$ & 5.33 & Prophiophenone derivative & 0.09 & 239.06 \\
\hline 43 & Kakuol & $\mathrm{C}_{10} \mathrm{H}_{10} \mathrm{O}_{4}$ & 5.71 & Prophiophenone derivative & 0.17 & 239.06 \\
\hline 44 & Aspidinol & $\mathrm{C}_{12} \mathrm{H}_{16} \mathrm{O}_{4}$ & 5.79 & Simple phenols & 0.18 & 269.10 \\
\hline 45 & Feroxin A & $\mathrm{C}_{17} \mathrm{H}_{24} \mathrm{O}_{8}$ & 5.80 & 3-O Glucoside & 0.19 & 401.14 \\
\hline 46 & Feroxin A & $\mathrm{C}_{17} \mathrm{H}_{24} \mathrm{O}_{8}$ & 5.80 & 3-O Glucoside & 0.20 & 401.14 \\
\hline 47 & Feroxin A & $\mathrm{C}_{17} \mathrm{H}_{24} \mathrm{O}_{8}$ & 5.80 & 3-O Glucoside & 2.25 & 401.14 \\
\hline 48 & Maclurin & $\mathrm{C}_{13} \mathrm{H}_{10} \mathrm{O}_{6}$ & 5.92 & Benzanoid phenolic & 0.41 & 261.04 \\
\hline 49 & $\begin{array}{l}\text { 4-(4'-Hydroxy-3',5'- } \\
\text { dimethoxyphenyl)-3- } \\
\text { buten-2-one }\end{array}$ & $\mathrm{C}_{12} \mathrm{H}_{14} \mathrm{O}_{4}$ & 6.01 & Simple phenol & 0.13 & 267.09 \\
\hline 50 & Moracin M-3'-O- $\beta$-Dglucopyranoside & $\mathrm{C}_{20} \mathrm{H}_{20} \mathrm{O}_{9}$ & 6.07 & Glycoside & 0.12 & 449.11 \\
\hline 51 & Protosappanin A & $\mathrm{C}_{15} \mathrm{H}_{12} \mathrm{O}_{5}$ & 6.09 & Dibenzoxocin derivative & 0.07 & 317.07 \\
\hline 52 & Methyl-5-Ocaffeoylquinate & $\mathrm{C}_{17} \mathrm{H}_{20} \mathrm{O}_{9}$ & 6.15 & Phenolic acid derivative & 0.07 & 413.11 \\
\hline 53 & $\begin{array}{l}\text { 3,4-Dihydroxy } \\
\text { phenethanol }\end{array}$ & $\mathrm{C}_{8} \mathrm{H}_{10} \mathrm{O}_{3}$ & 6.26 & Simple phenol & 0.15 & 153.06 \\
\hline 54 & Cimidahurine & $\mathrm{C}_{14} \mathrm{H}_{20} \mathrm{O}_{8}$ & 6.27 & Phenylpropanoid glycoside & 0.56 & 315.11 \\
\hline 55 & Cimidahurine & $\mathrm{C}_{14} \mathrm{H}_{20} \mathrm{O}_{8}$ & 6.27 & Phenylpropanoid glycoside & 0.08 & 315.11 \\
\hline 56 & Aspidinol & $\mathrm{C}_{12} \mathrm{H}_{16} \mathrm{O}_{4}$ & 6.29 & Simple phenols & 0.18 & 223.10 \\
\hline 57 & Protosappanin C & $\mathrm{C}_{16} \mathrm{H}_{14} \mathrm{O}_{6}$ & 6.30 & Dibenzoxocin derivative & 0.12 & 347.08 \\
\hline 58 & 10-OMethyl-protosappanin B & $\mathrm{C}_{17} \mathrm{H}_{8} \mathrm{O}_{6}$ & 6.41 & Dibenzoxocin derivative & 0.11 & 363.11 \\
\hline 59 & Cassialactone & $\mathrm{C}_{16} \mathrm{H}_{16} \mathrm{O}_{6}$ & 6.43 & Simple phenol & 0.08 & 349.09 \\
\hline 60 & $\begin{array}{l}\text { 2,7-Dihydroxy-4- } \\
\text { methoxyphenanthrene- } \\
\text { 2-O-glucoside }\end{array}$ & $\mathrm{C}_{21} \mathrm{H}_{22} \mathrm{O}_{8}$ & 6.43 & Phenanthrene phenol & 0.14 & 447.13 \\
\hline 61 & $\begin{array}{l}\text { 1-O-Methyl-3,5 Odicaffeoylquinic acid } \\
\text { methyl ester }\end{array}$ & $\mathrm{C}_{27} \mathrm{H}_{28} \mathrm{O}_{12}$ & 6.45 & Phenolic acid & 0.08 & 589.16 \\
\hline 62 & Kakuol & $\mathrm{C}_{10} \mathrm{H}_{10} \mathrm{O}_{4}$ & 6.47 & Prophiophenone derivative & 0.40 & 239.06 \\
\hline 63 & Aspidinol & $\mathrm{C}_{12} \mathrm{H}_{16} \mathrm{O}_{4}$ & 6.49 & Simple phenols & 0.11 & 223.10 \\
\hline 64 & Dihydroeugenol & $\mathrm{C}_{10} \mathrm{H}_{14} \mathrm{O}_{2}$ & 6.53 & Simple phenols & 0.13 & 211.10 \\
\hline 65 & Ciwujiatone & $\mathrm{C}_{22} \mathrm{H}_{26} \mathrm{O}_{9}$ & 6.59 & Lignan & 0.06 & 433.15 \\
\hline 66 & Phenol & $\mathrm{C}_{6} \mathrm{H}_{6} \mathrm{O}$ & 6.91 & Simple phenols & 0.08 & 139.04 \\
\hline 67 & $\begin{array}{l}\text { 2,7-Dihydroxy-4- } \\
\text { methoxyphenanthrene- } \\
\text { 2-O-glucoside }\end{array}$ & $\mathrm{C}_{21} \mathrm{H}_{22} \mathrm{O}_{8}$ & 6.96 & Phenanthrene phenol & 0.19 & 447.13 \\
\hline 68 & Nobilin D & $\mathrm{C}_{16} \mathrm{H}_{18} \mathrm{O}_{6}$ & 6.97 & Prenol lipid & 0.07 & 305.10 \\
\hline 69 & $\begin{array}{l}\text { 3,7-Dihydroxy-2,4- } \\
\text { dimethoxyphenanthren } \\
\text { e-3-O-glucoside }\end{array}$ & $\mathrm{C}_{22} \mathrm{H}_{24} \mathrm{O}_{9}$ & 6.99 & Phenanthrene phenol & 0.09 & 477.14 \\
\hline 70 & Cimidahurine & $\mathrm{C}_{14} \mathrm{H}_{20} \mathrm{O}_{8}$ & 7.05 & Phenylpropanoid glycoside & 0.17 & 315.11 \\
\hline 71 & Kakuol & $\mathrm{C}_{10} \mathrm{H}_{10} \mathrm{O}_{4}$ & 7.13 & Prophiophenone derivative & 0.09 & 239.06 \\
\hline 72 & Kakuol & $\mathrm{C}_{10} \mathrm{H}_{10} \mathrm{O}_{4}$ & 7.13 & Prophiophenone derivative & 0.16 & 239.06 \\
\hline 73 & Phenol & $\mathrm{C}_{6} \mathrm{H}_{6} \mathrm{O}$ & 7.14 & Simple phenols & 0.40 & 139.04 \\
\hline 74 & Phenol & $\mathrm{C}_{6} \mathrm{H}_{6} \mathrm{O}$ & 7.14 & Simple phenols & 0.19 & 139.04 \\
\hline 75 & Kakuol & $\mathrm{C}_{10} \mathrm{H}_{10} \mathrm{O}_{4}$ & 7.14 & Prophiophenone derivative & 1.17 & 239.06 \\
\hline 76 & Tachioside & $\mathrm{C}_{13} \mathrm{H}_{18} \mathrm{O}_{8}$ & 7.15 & Phenolic glycoside & 0.74 & 301.09 \\
\hline 77 & Phenol & $\mathrm{C}_{6} \mathrm{H}_{6} \mathrm{O}$ & 7.15 & Simple phenols & 0.16 & 139.04 \\
\hline
\end{tabular}




\begin{tabular}{|c|c|c|c|c|c|c|}
\hline 78 & Moracin F & $\mathrm{C}_{16} \mathrm{H}_{14} \mathrm{O}_{5}$ & 7.16 & 2-arylbenzofuran flavanoid & 0.69 & 285.08 \\
\hline 79 & Gingerone & $\mathrm{C}_{11} \mathrm{H}_{14} \mathrm{O}_{3}$ & 7.26 & Simple phenols & 0.41 & 239.09 \\
\hline 80 & Dihydroeugenol & $\mathrm{C}_{10} \mathrm{H}_{14} \mathrm{O}_{2}$ & 7.28 & Simple phenols & 0.53 & 211.10 \\
\hline 81 & $\begin{array}{l}2,3,5,4 \text { '- } \\
\text { Tetrahydroxystilbene-2-O- } \beta \text {-D- } \\
\text { glucopyranoside }\end{array}$ & $\mathrm{C}_{20} \mathrm{H}_{22} \mathrm{O}_{9}$ & 7.39 & Glucoside & 0.07 & 405.12 \\
\hline 82 & Cassialactone & $\mathrm{C}_{16} \mathrm{H}_{16} \mathrm{O}_{6}$ & 7.41 & Simple phenol & 0.24 & 349.09 \\
\hline 83 & Nobilone & $\mathrm{C}_{14} \mathrm{H}_{10} \mathrm{O}_{4}$ & 7.42 & Simple phenols & 0.18 & 287.06 \\
\hline 84 & Gingerone & $\mathrm{C}_{11} \mathrm{H}_{14} \mathrm{O}_{3}$ & 7.42 & Simple phenols & 0.67 & 239.09 \\
\hline 85 & Nobilone & $\mathrm{C}_{14} \mathrm{H}_{10} \mathrm{O}_{4}$ & 7.45 & Simple phenols & 0.96 & 287.06 \\
\hline 86 & Homoarbutin & $\mathrm{C}_{13} \mathrm{H}_{18} \mathrm{O}_{7}$ & 7.49 & Glucoside & 0.09 & 331.10 \\
\hline 87 & Apocynin B & $\mathrm{C}_{24} \mathrm{H}_{20} \mathrm{O}_{10}$ & 7.50 & Simple phenol & 0.13 & 513.11 \\
\hline 88 & Dihydroeugenol & $\mathrm{C}_{10} \mathrm{H}_{14} \mathrm{O}_{2}$ & 7.55 & Simple phenol & 2.42 & 211.10 \\
\hline 89 & 3,4-Dimethoxyphenol & $\mathrm{C}_{8} \mathrm{H}_{10} \mathrm{O}_{3}$ & 7.56 & Simple phenol & 0.33 & 153.06 \\
\hline 90 & Kakuol & $\mathrm{C}_{10} \mathrm{H}_{10} \mathrm{O}_{4}$ & 7.56 & Prophiophenone derivative & 0.35 & 239.06 \\
\hline 91 & Cimidahurine & $\mathrm{C}_{14} \mathrm{H}_{20} \mathrm{O}_{8}$ & 7.56 & Phenylpropanoid glycoside & 1.39 & 315.11 \\
\hline 92 & Echinacoside & $\mathrm{C}_{35} \mathrm{H}_{46} \mathrm{O}_{20}$ & 7.56 & Glucoside & 1.60 & 831.26 \\
\hline 93 & Sinapaldehyde & $\mathrm{C}_{11} \mathrm{H}_{12} \mathrm{O}_{4}$ & 7.57 & Lignin & 3.56 & 253.07 \\
\hline 94 & 3,4-Dimethoxyphenol & $\mathrm{C}_{8} \mathrm{H}_{10} \mathrm{O}_{3}$ & 7.57 & Simple phenol & 0.12 & 153.06 \\
\hline 95 & Eugenol & $\mathrm{C}_{10} \mathrm{H}_{12} \mathrm{O}_{2}$ & 7.57 & Simple phenol & 0.07 & 209.08 \\
\hline 96 & Brazilin & $\mathrm{C}_{16} \mathrm{H}_{14} \mathrm{O}_{5}$ & 7.60 & Pigment phenol & 1.19 & 285.08 \\
\hline 97 & Tachioside & $\mathrm{C}_{13} \mathrm{H}_{18} \mathrm{O}_{8}$ & 7.64 & Phenolic glycoside & 0.07 & 301.09 \\
\hline 98 & $\begin{array}{l}\text { 2-Hydroxy-4- } \\
\text { methoxybenzaldehyde }\end{array}$ & $\mathrm{C}_{8} \mathrm{H}_{8} \mathrm{O}_{3}$ & 7.70 & Simple phenol & 0.34 & 151.04 \\
\hline 99 & Ellagic acid & $\mathrm{C}_{14} \mathrm{H}_{6} \mathrm{O}_{8}$ & 7.72 & Phenolic acid & 0.08 & 300.99 \\
\hline 100 & Aspidinol & $\mathrm{C}_{12} \mathrm{H}_{16} \mathrm{O}_{4}$ & 7.81 & Simple phenols & 0.09 & 269.10 \\
\hline 101 & Moracin F & $\mathrm{C}_{16} \mathrm{H}_{14} \mathrm{O}_{5}$ & 7.83 & Flavanoid & 0.22 & 285.08 \\
\hline 102 & Tachioside & $\mathrm{C}_{13} \mathrm{H}_{18} \mathrm{O}_{8}$ & 7.84 & Phenolic glycoside & 0.19 & 301.09 \\
\hline 103 & Phenol & $\mathrm{C}_{6} \mathrm{H}_{6} \mathrm{O}$ & 7.84 & Simple phenols & 0.16 & 139.04 \\
\hline 104 & Renifolin & $\mathrm{C}_{18} \mathrm{H}_{24} \mathrm{O}_{7}$ & 8.02 & Glucoside & 0.25 & 397.15 \\
\hline 105 & Nobilone & $\mathrm{C}_{14} \mathrm{H}_{10} \mathrm{O}_{4}$ & 8.12 & Simple phenols & 0.22 & 287.06 \\
\hline 106 & Protosappanin C & $\mathrm{C}_{16} \mathrm{H}_{14} \mathrm{O}_{6}$ & 8.16 & Dibenzoxocin derivative & 0.09 & 301.07 \\
\hline 107 & 3,4-Dihydroxybenzamide & $\mathrm{C}_{7} \mathrm{H}_{7} \mathrm{NO}_{3}$ & 8.18 & Amide phenol & 0.09 & 152.04 \\
\hline 108 & 3,4-Dihydroxybenzamide & $\mathrm{C}_{7} \mathrm{H}_{7} \mathrm{NO}_{3}$ & 8.18 & Amide phenol & 0.09 & 152.04 \\
\hline 109 & $( \pm)$-Isoduartin & $\mathrm{C}_{18} \mathrm{H}_{20} \mathrm{O}_{6}$ & 8.24 & Isoflavan & 0.26 & 377.12 \\
\hline 110 & Renifolin & $\mathrm{C}_{18} \mathrm{H}_{24} \mathrm{O}_{7}$ & 8.31 & Glucoside & 0.10 & 397.15 \\
\hline 111 & Aspidinol & $\mathrm{C}_{12} \mathrm{H}_{16} \mathrm{O}_{4}$ & 8.42 & Simple phenols & 0.21 & 269.10 \\
\hline 112 & Eugenol & $\mathrm{C}_{10} \mathrm{H}_{12} \mathrm{O}_{2}$ & 8.47 & Simple phenols & 0.12 & 209.08 \\
\hline 113 & Gingerone & $\mathrm{C}_{11} \mathrm{H}_{14} \mathrm{O}_{3}$ & 8.53 & Simple phenols & 3.48 & 239.09 \\
\hline 114 & Obovatol & $\mathrm{C}_{18} \mathrm{H}_{18} \mathrm{O}_{3}$ & 8.55 & Biphenolic & 0.07 & 327.12 \\
\hline 115 & $\begin{array}{l}2^{\prime} \text {-Hydroxy- } 7,3^{\prime}, 4^{\prime}- \\
\text { trimethoxy-isoflavan }\end{array}$ & $\mathrm{C}_{18} \mathrm{H}_{20} \mathrm{O}_{5}$ & 8.55 & Isoflavan & 0.16 & 315.12 \\
\hline 116 & Arbutin & $\mathrm{C}_{12} \mathrm{H}_{16} \mathrm{O}_{7}$ & 8.60 & Glucoside & 0.11 & 317.09 \\
\hline 117 & Moracin F & $\mathrm{C}_{16} \mathrm{H}_{14} \mathrm{O}_{5}$ & 8.62 & 2-arylbenzofuran flavanoid & 0.19 & 285.08 \\
\hline 118 & Smilaxin & $\mathrm{C}_{17} \mathrm{H}_{16} \mathrm{O}_{6}$ & 8.63 & Streoid glycoside & 0.09 & 361.09 \\
\hline 119 & $\begin{array}{l}\text { 3,7-Dihydroxy-2,4- } \\
\text { dimethoxyphenanthren } \\
\text { e-3-O-glucoside }\end{array}$ & $\mathrm{C}_{22} \mathrm{H}_{24} \mathrm{O}_{9}$ & 8.64 & Glucoside & 0.52 & 477.14 \\
\hline 120 & $\begin{array}{l}\text { 3,7-Dihydroxy-2,4- } \\
\text { dimethoxyphenanthren } \\
\text { e-3-O-glucoside }\end{array}$ & $\mathrm{C}_{22} \mathrm{H}_{24} \mathrm{O}_{9}$ & 8.64 & Phenanthrene glucoside & 0.16 & 477.14 \\
\hline 121 & $\begin{array}{l}\text { 2,4,7-Trihydroxy-9,10- } \\
\text { dihydrophenanthrene }\end{array}$ & $\mathrm{C}_{14} \mathrm{H}_{12} \mathrm{O}_{3}$ & 8.72 & Phenanthrene phenol & 2.96 & 273.08 \\
\hline 122 & $\begin{array}{l}\text { 4-(4'-Hydroxy-3', } 5^{\prime}- \\
\text { dimethoxyphenyl)-3- } \\
\text { buten-2-one }\end{array}$ & $\mathrm{C}_{12} \mathrm{H}_{14} \mathrm{O}_{4}$ & 9.02 & Simple phenol & 0.24 & 267.09 \\
\hline 123 & Torachrysone-8-O- $\beta$-Dglucopyranoside & $\mathrm{C}_{20} \mathrm{H}_{24} \mathrm{O}_{9}$ & 9.04 & Glucoside & 0.12 & 407.14 \\
\hline 124 & Brazilein & $\mathrm{C}_{16} \mathrm{H}_{12} \mathrm{O}_{5}$ & 9.08 & Simple phenols & 0.10 & \\
\hline 125 & Moracin F & $\mathrm{C}_{16} \mathrm{H}_{14} \mathrm{O}_{5}$ & 9.09 & 2-arylbenzofuran flavanoid & 0.16 & 285.08 \\
\hline 126 & Aspidinol & $\mathrm{C}_{12} \mathrm{H}_{16} \mathrm{O}_{4}$ & 9.15 & Simple phenols & 0.68 & 269.10 \\
\hline
\end{tabular}




\begin{tabular}{|c|c|c|c|c|c|c|}
\hline 127 & $\begin{array}{l}\text { 4-(4'-Hydroxy-3',5'- } \\
\text { dimethoxyphenyl)-3- } \\
\text { buten-2-one }\end{array}$ & $\mathrm{C}_{12} \mathrm{H}_{14} \mathrm{O}_{4}$ & 9.24 & Simple phenols & 0.10 & 267.09 \\
\hline 128 & $\begin{array}{l}\text { 4-(4'-Hydroxy-3',5'- } \\
\text { dimethoxyphenyl)-3- } \\
\text { buten-2-one }\end{array}$ & $\mathrm{C}_{12} \mathrm{H}_{14} \mathrm{O}_{4}$ & 9.26 & Simple phenols & 0.07 & 267.09 \\
\hline 129 & Polydatin & $\mathrm{C}_{20} \mathrm{H}_{22} \mathrm{O}_{8}$ & 9.42 & Glycoside & 0.12 & 435.13 \\
\hline 130 & Echinacoside & $\mathrm{C}_{35} \mathrm{H}_{46} \mathrm{O}_{20}$ & 9.42 & Phenyl propanoid glucoside & 1.57 & 831.26 \\
\hline 131 & Sinapaldehyde & $\mathrm{C}_{11} \mathrm{H}_{12} \mathrm{O}_{4}$ & 9.42 & Lignin intermediate & 1.80 & 253.07 \\
\hline 132 & 3,4-Dimethoxyphenol & $\mathrm{C}_{8} \mathrm{H}_{10} \mathrm{O}_{3}$ & 9.43 & Simple phenol & 0.06 & 153.06 \\
\hline 133 & Cimidahurine & $\mathrm{C}_{14} \mathrm{H}_{20} \mathrm{O}_{8}$ & 9.43 & Phenylpropanoid glycoside & 0.36 & 315.11 \\
\hline 134 & \pm )-Isoduartin & $\mathrm{C}_{18} \mathrm{H}_{20} \mathrm{O}_{6}$ & 9.43 & Isoflavan & 1.38 & 377.12 \\
\hline 135 & Nobilone & $\mathrm{C}_{14} \mathrm{H}_{10} \mathrm{O}_{4}$ & 9.51 & Simple phenols & 0.11 & 287.06 \\
\hline 136 & $\begin{array}{l}\text { 4-(4'-Hydroxy-3',5'- } \\
\text { dimethoxyphenyl)-3- } \\
\text { buten-2-one }\end{array}$ & $\mathrm{C}_{12} \mathrm{H}_{14} \mathrm{O}_{4}$ & 9.53 & Simple phenol & 0.12 & 267.09 \\
\hline 137 & $\begin{array}{l}\text { 4-(4'-Hydroxy-3',5'- } \\
\text { dimethoxyphenyl)-3- } \\
\text { buten-2-one }\end{array}$ & $\mathrm{C}_{12} \mathrm{H}_{14} \mathrm{O}_{4}$ & 9.54 & Simple phenol & 0.60 & 267.09 \\
\hline 138 & Kuzubutenolide A & $\mathrm{C}_{23} \mathrm{H}_{24} \mathrm{O}_{10}$ & 9.64 & Glucoside & 0.10 & 459.13 \\
\hline 139 & Moracin C & $\mathrm{C}_{19} \mathrm{H}_{18} \mathrm{O}_{4}$ & 9.65 & Glucoside & 0.26 & 355.12 \\
\hline 140 & Albaspidin AA & $\mathrm{C}_{21} \mathrm{H}_{24} \mathrm{O}_{8}$ & 9.76 & Phloroglucinol derivative & 0.24 & 449.15 \\
\hline 141 & Renifolin & $\mathrm{C}_{18} \mathrm{H}_{24} \mathrm{O}_{7}$ & 9.81 & Glucoside & 0.16 & 397.15 \\
\hline 142 & Aspidinol & $\mathrm{C}_{12} \mathrm{H}_{16} \mathrm{O}_{4}$ & 9.86 & Simple phenols & 1.23 & 269.10 \\
\hline 143 & Gingerone & $\mathrm{C}_{11} \mathrm{H}_{14} \mathrm{O}_{3}$ & 9.87 & Simple phenols & 0.70 & 239.09 \\
\hline 144 & Nobilin B & $\mathrm{C}_{17} \mathrm{H}_{20} \mathrm{O}_{6}$ & 10.07 & Prenol lipid & 0.11 & 319.12 \\
\hline 145 & Torachrysone-8-O- $\beta$-Dglucopyranoside & $\mathrm{C}_{20} \mathrm{H}_{24} \mathrm{O}_{9}$ & 10.10 & Glucoside & 0.12 & 407.14 \\
\hline 146 & Nobilin C & $\mathrm{C}_{18} \mathrm{H}_{22} \mathrm{O}_{6}$ & 10.10 & Prenol lipid & 0.16 & 379.14 \\
\hline 147 & 1-Galloyl-glucose & $\mathrm{C}_{13} \mathrm{H}_{16} \mathrm{O}_{10}$ & 10.14 & Gallotannin & 0.09 & 331.07 \\
\hline 148 & Asebotin & $\mathrm{C}_{22} \mathrm{H}_{26} \mathrm{O}_{10}$ & 10.15 & Dihydrochalcone glucoside & 0.24 & 449.15 \\
\hline 149 & Renifolin & $\mathrm{C}_{18} \mathrm{H}_{24} \mathrm{O}_{7}$ & 10.20 & Glucoside & 0.21 & 397.15 \\
\hline 150 & $\begin{array}{l}\text { 3,4-O-Dicaffeoylquinic } \\
\text { acid }\end{array}$ & $\mathrm{C}_{25} \mathrm{H}_{24} \mathrm{O}_{12}$ & 10.33 & Phenolic acid & 0.09 & 561.13 \\
\hline 151 & $\begin{array}{l}\text { 2-((3R,4R)-7-Hydroxy-4- } \\
\text { (4-hydroxy-5-((R)-7- } \\
\text { hydroxychroman-3-yl)-2-methoxyphenyl) } \\
\text { chroman3-yl)-5-methoxycyclohexa 2,5-di- } \\
\text { ene-1,4-dione }\end{array}$ & $\mathrm{C}_{32} \mathrm{H}_{28} \mathrm{O}_{9}$ & 10.36 & Simple phenol & 0.09 & 555.17 \\
\hline 152 & Asebotin & $\mathrm{C}_{22} \mathrm{H}_{26} \mathrm{O}_{10}$ & 10.49 & Dihydrochalcone glucoside & 0.09 & 449.15 \\
\hline 153 & Sinapaldehyde & $\mathrm{C}_{11} \mathrm{H}_{12} \mathrm{O}_{4}$ & 10.59 & Lignin intermediate & 0.43 & 253.07 \\
\hline 154 & $\begin{array}{l}\text { 2,4,7-Trihydroxy-9,10- } \\
\text { dihydrophenanthrene }\end{array}$ & $\mathrm{C}_{14} \mathrm{H}_{12} \mathrm{O}_{3}$ & 10.59 & Phenanthrene phenol & 2.99 & 273.08 \\
\hline 155 & p-Tolualdehyde & $\mathrm{C}_{7} \mathrm{H}_{6} \mathrm{O}_{2}$ & 10.59 & Benzenoid & 0.07 & 167.04 \\
\hline 156 & Ciwujiatone & $\mathrm{C}_{22} \mathrm{H}_{26} \mathrm{O}_{9}$ & 10.66 & Lignan & 0.13 & 433.15 \\
\hline 157 & Cearoin & $\mathrm{C}_{14} \mathrm{H}_{12} \mathrm{O}_{4}$ & 10.66 & Simple phenol & 0.29 & 289.07 \\
\hline 158 & Albaspidin AA & $\mathrm{C}_{21} \mathrm{H}_{24} \mathrm{O}_{8}$ & 10.67 & Phloroglucinol derivative & 0.11 & 403.14 \\
\hline 159 & Torachrysone-8-O- $\beta$-Dglucopyranoside & $\mathrm{C}_{20} \mathrm{H}_{24} \mathrm{O}_{9}$ & 10.75 & Glucoside & 0.54 & 407.14 \\
\hline 160 & Ciwujiatone & $\mathrm{C}_{22} \mathrm{H}_{26} \mathrm{O}_{9}$ & 10.81 & Lignan & 0.10 & 433.15 \\
\hline 161 & Cassialactone & $\mathrm{C}_{16} \mathrm{H}_{16} \mathrm{O}_{6}$ & 10.84 & Simple phenol & 0.08 & 349.09 \\
\hline 162 & Renifolin & $\mathrm{C}_{18} \mathrm{H}_{24} \mathrm{O}_{7}$ & 10.90 & Glucoside & 0.34 & 397.15 \\
\hline 163 & $\begin{array}{l}\text { 4-(4'-Hydroxy-3',5'- } \\
\text { dimethoxyphenyl)-3- } \\
\text { buten-2-one }\end{array}$ & $\mathrm{C}_{12} \mathrm{H}_{14} \mathrm{O}_{4}$ & 10.91 & Simple phenol & 0.12 & 267.09 \\
\hline 164 & Sinapaldehyde & $\mathrm{C}_{11} \mathrm{H}_{12} \mathrm{O}_{4}$ & 10.97 & Lignin intermediate & 0.64 & 253.07 \\
\hline 165 & $\begin{array}{l}\text { 4,4'-Dihydroxy-3,5- } \\
\text { dimethoxybibenzyl }\end{array}$ & $\mathrm{C}_{16} \mathrm{H}_{18} \mathrm{O}_{4}$ & 11.03 & & 0.28 & 319.12 \\
\hline 166 & Protosappanin A & $\mathrm{C}_{15} \mathrm{H}_{12} \mathrm{O}_{5}$ & 11.07 & Dibenzoxocin derivative & 0.34 & 271.06 \\
\hline 167 & Aspidinol & $\mathrm{C}_{12} \mathrm{H}_{16} \mathrm{O}_{4}$ & 11.13 & Simple phenols & 0.33 & 223.10 \\
\hline 168 & Thannilignan & $\mathrm{C}_{19} \mathrm{H}_{22} \mathrm{O}_{5}$ & 11.15 & Lignan & 0.34 & 329.14 \\
\hline 169 & Sinapaldehyde & $\mathrm{C}_{11} \mathrm{H}_{12} \mathrm{O}_{4}$ & 11.17 & Lignin intermediate & 0.64 & 253.07 \\
\hline 170 & Cistanoside $\mathrm{H}$ & $\mathrm{C}_{22} \mathrm{H}_{32} \mathrm{O}_{13}$ & 11.26 & Glucoside & 0.20 & 503.18 \\
\hline 171 & Renifolin & $\mathrm{C}_{13} \mathrm{H}_{2} \mathrm{O}_{7}$ & 11.30 & Glucoside & 0.15 & 397.15 \\
\hline
\end{tabular}




\begin{tabular}{|c|c|c|c|c|c|c|}
\hline 172 & Protosappanin A & $\mathrm{C}_{15} \mathrm{H}_{12} \mathrm{O}_{5}$ & 11.43 & Dibenzoxocin derivative & 1.18 & 271.06 \\
\hline 173 & $\begin{array}{l}2,3,5,4 \text { '- } \\
\text { Tetrahydroxystilbene-2-O-(6"-O- } \alpha \text { - } \\
\text { glucopyranosyl)- } \\
\beta \text {-Dglucopyranoside }\end{array}$ & $\mathrm{C}_{26} \mathrm{H}_{32} \mathrm{O}_{14}$ & 11.53 & Glucoside & 0.17 & 567.17 \\
\hline 174 & Dendrocandin C & $\mathrm{C}_{16} \mathrm{H}_{18} \mathrm{O}_{5}$ & 11.55 & Bibenzyl phenols & 0.38 & 289.11 \\
\hline 175 & $\begin{array}{l}\text { 3,4- } \\
\text { Dihydroxybenzamide }\end{array}$ & $\mathrm{C}_{7} \mathrm{H}_{7} \mathrm{NO}_{3}$ & 11.57 & 8380 & 0.27 & 152.04 \\
\hline 176 & Thannilignan & $\mathrm{C}_{19} \mathrm{H}_{22} \mathrm{O}_{5}$ & 11.78 & Lignan & 0.18 & 375.15 \\
\hline 177 & Cistanoside H & $\mathrm{C}_{22} \mathrm{H}_{32} \mathrm{O}_{13}$ & 11.80 & Glucoside & 0.08 & 503.18 \\
\hline 178 & p-Tolualdehyde & $\mathrm{C}_{7} \mathrm{H}_{6} \mathrm{O}_{2}$ & 11.88 & Benzenoid & 0.57 & 167.04 \\
\hline 179 & 2,4,7-Trihydroxy-9,10-dihydrophenanthrene & $\mathrm{C}_{14} \mathrm{H}_{12} \mathrm{O}_{3}$ & 11.90 & Phenanthrene phenol & 14.36 & 273.08 \\
\hline 180 & Tachioside & $\mathrm{C}_{13} \mathrm{H}_{18} \mathrm{O}_{8}$ & 11.90 & Phenolic glycoside & 0.21 & 301.09 \\
\hline 181 & Eugenol & $\mathrm{C}_{10} \mathrm{H}_{12} \mathrm{O}_{2}$ & 11.96 & Simple phenol & 0.17 & 209.08 \\
\hline 182 & 3,4-Dimethoxyphenol & $\mathrm{C}_{8} \mathrm{H}_{10} \mathrm{O}_{3}$ & 11.97 & Simple phenol & 0.45 & 153.06 \\
\hline 183 & Sinapaldehyde & $\mathrm{C}_{11} \mathrm{H}_{12} \mathrm{O}_{4}$ & 11.97 & Lignin intermediate & 0.72 & 253.07 \\
\hline 184 & $\begin{array}{l}2,3,5,4^{\prime}- \\
\text { Tetrahydroxystilbene-2-O-(6"-O- } \alpha \text { - } \\
\text { Dglucopyranosyl)- } \\
\beta \text {-Dglucopyranoside }\end{array}$ & $\mathrm{C}_{26} \mathrm{H}_{32} \mathrm{O}_{14}$ & 12.04 & Glucoside & 0.12 & 567.17 \\
\hline 185 & Phenol & $\mathrm{C}_{6} \mathrm{H}_{6} \mathrm{O}$ & 12.09 & Simple phenols & 1.15 & 139.04 \\
\hline 186 & $\begin{array}{l}\text { 10-OMethyl } \\
\text { protosappanin B }\end{array}$ & $\mathrm{C}_{17} \mathrm{H}_{18} \mathrm{O}_{6}$ & 12.16 & Dibenzoxocin derivative & 0.08 & 363.11 \\
\hline 187 & Phenol & $\mathrm{C}_{6} \mathrm{H}_{6} \mathrm{O}$ & 12.36 & Simple phenols & 0.09 & 139.04 \\
\hline 188 & $\begin{array}{l}\text { 1,4-Dihydroxy-2- } \\
\text { methoxybenzene }\end{array}$ & $\mathrm{C}_{7} \mathrm{H}_{8} \mathrm{O}_{3}$ & 12.37 & Benzenoid & 1.10 & 139.04 \\
\hline 189 & tran-Ferulaldehyde & $\mathrm{C}_{10} \mathrm{H}_{10} \mathrm{O}_{3}$ & 12.37 & Aldehyde & 0.10 & 223.06 \\
\hline 190 & (3R)-3',8-Dihydroxyvestitol & $\mathrm{C}_{16} \mathrm{H}_{16} \mathrm{O}_{6}$ & 12.51 & Isoflavane & 0.15 & 349.09 \\
\hline 191 & Caesalpins J & $\mathrm{C}_{17} \mathrm{H}_{16} \mathrm{O}_{6}$ & 12.59 & Simple phenol & 0.08 & 361.09 \\
\hline 192 & Polydatin & $\mathrm{C}_{20} \mathrm{H}_{22} \mathrm{O}_{8}$ & 12.67 & Glucoside & 0.08 & 435.13 \\
\hline 193 & $\begin{array}{l}2,3,5,4^{\prime}- \\
\text { Tetrahydroxystilbene-2,3-O- } \beta \text { - } \\
\text { Dglucopyranoside }\end{array}$ & $\mathrm{C}_{26} \mathrm{H}_{32} \mathrm{O}_{14}$ & 12.80 & Glucoside & 0.16 & 567.17 \\
\hline 194 & Aspidinol & $\mathrm{C}_{12} \mathrm{H}_{16} \mathrm{O}_{4}$ & 12.88 & Simple phenol & 0.12 & 223.10 \\
\hline 195 & Aspidinol & $\mathrm{C}_{12} \mathrm{H}_{16} \mathrm{O}_{4}$ & 12.88 & Simple phenol & 0.35 & 223.10 \\
\hline 196 & Protosappanin A & $\mathrm{C}_{15} \mathrm{H}_{12} \mathrm{O}_{5}$ & 13.10 & Dibenzoxocin derivative & 0.35 & 271.06 \\
\hline 197 & Darendoside A & $\mathrm{C}_{19} \mathrm{H}_{28} \mathrm{O}_{11}$ & 13.15 & $\begin{array}{l}\text { Phenethyl alcohol glyco- } \\
\text { sides }\end{array}$ & 0.41 & 431.16 \\
\hline 198 & Moracin M-3'-O- $\beta$-Dglucopyranoside & $\mathrm{C}_{20} \mathrm{H}_{20} \mathrm{O}_{9}$ & 13.38 & Glucoside & 0.12 & 403.10 \\
\hline 199 & Dendrocandin C & $\mathrm{C}_{16} \mathrm{H}_{18} \mathrm{O}_{5}$ & 13.43 & Bibenzyl phenols & 0.09 & 289.11 \\
\hline 200 & $\begin{array}{l}7,2^{\prime}, 3^{\prime} \text {-Trihydroxy-4'- } \\
\text { methoxy-isoflavan }\end{array}$ & $\mathrm{C}_{16} \mathrm{H}_{16} \mathrm{O}_{5}$ & 14.14 & Isoflavane & 0.28 & 287.09 \\
\hline 201 & $\begin{array}{l}2,3,5,4 \text { '- } \\
\text { Tetrahydroxystilbene-2-O-(6"-O- } \alpha \text { - } \\
\text { Dglucopyranosyl)- } \\
\beta \text {-Dglucopyranoside }\end{array}$ & $\mathrm{C}_{26} \mathrm{H}_{32} \mathrm{O}_{14}$ & 14.27 & Glucoside & 0.10 & 567.17 \\
\hline 202 & Dendrocandin C & $\mathrm{C}_{16} \mathrm{H}_{18} \mathrm{O}_{5}$ & 14.59 & Bibenzyl phenols & 0.10 & 335.11 \\
\hline 203 & Aspidinol & $\mathrm{C}_{12} \mathrm{H}_{16} \mathrm{O}_{4}$ & 15.01 & Simple phenol & 1.05 & 223.10 \\
\hline 204 & Moracin M-3'-O- $\beta$-Dglucopyranoside & $\mathrm{C}_{20} \mathrm{H}_{20} \mathrm{O}_{9}$ & 16.84 & Glucoside & 0.08 & 403.10 \\
\hline 205 & Dendrocandin E & $\mathrm{C}_{15} \mathrm{H}_{16} \mathrm{O}_{5}$ & 16.87 & Bibenzyl phenols & 0.13 & 321.10 \\
\hline 206 & Xanthohumol & $\mathrm{C}_{21} \mathrm{H}_{22} \mathrm{O}_{5}$ & 16.91 & Chalcone & 0.08 & 399.15 \\
\hline 207 & $\begin{array}{l}\text { 2,7-Dihydroxy-4- } \\
\text { methoxyphenanthrene- } \\
\text { 2-O-glucoside }\end{array}$ & $\mathrm{C}_{21} \mathrm{H}_{22} \mathrm{O}_{8}$ & 16.91 & Phenanthrene phenol & 0.15 & 447.13 \\
\hline 208 & Kuzubutenolide A & $\mathrm{C}_{23} \mathrm{H}_{24} \mathrm{O}_{10}$ & 17.26 & Glucoside & 0.07 & 505.13 \\
\hline 209 & Cyclocurcumin & $\mathrm{C}_{21} \mathrm{H}_{20} \mathrm{O}_{6}$ & 17.26 & Diarylheptanoid & 0.10 & 413.12 \\
\hline 210 & Dendrocandin E & $\mathrm{C}_{15} \mathrm{H}_{16} \mathrm{O}_{5}$ & 17.26 & Bibenzyl phenols & 0.15 & 321.10 \\
\hline 211 & Nobilin A & $\mathrm{C}_{17} \mathrm{H}_{20} \mathrm{O}_{5}$ & 17.26 & Prenol lipid & 0.09 & 349.13 \\
\hline 212 & Syringylethanone & $\mathrm{C}_{10} \mathrm{H}_{12} \mathrm{O}_{4}$ & 17.26 & Lignin & 0.10 & 241.07 \\
\hline 213 & Dendrocandin C & $\mathrm{C}_{16} \mathrm{H}_{18} \mathrm{O}_{5}$ & 17.36 & Bibenzyl phenols & 0.07 & 335.11 \\
\hline 214 & Polydatin & $\mathrm{C}_{20} \mathrm{H}_{22} \mathrm{O}_{8}$ & 17.56 & Glycoside & 0.08 & 435.13 \\
\hline 215 & Moracin O & $\mathrm{C}_{19} \mathrm{H}_{18} \mathrm{O}_{5}$ & 17.89 & Glucoside & 0.17 & 371.11 \\
\hline 216 & Gigantol & $\mathrm{C}_{15} \mathrm{H}_{1} \mathrm{O}_{4}$ & 17.95 & Bibenzyl phenols & 0.07 & 305.10 \\
\hline
\end{tabular}

Note. RT: Retention Time, $\left[\mathrm{M}^{+}\right]$: Molecular ion mass $(\mathrm{m} / \mathrm{z})$ 
Table 5: Phytochemical compounds in F1ASP using LC-MS.

\begin{tabular}{|c|c|c|c|c|c|c|}
\hline No. & Compound & $\begin{array}{l}\text { Molecular } \\
\text { Formula }\end{array}$ & RT (min) & Chemical Classes & Response \% & {$\left[\mathrm{M}^{+}\right]$} \\
\hline 1 & 1-Galloyl-glucose & $\mathrm{C}_{13} \mathrm{H}_{16} \mathrm{O}_{10}$ & 0.44 & Gallotannin & 2.25 & 331.07 \\
\hline 2 & 1-Galloyl-glucose & $\mathrm{C}_{13} \mathrm{H}_{16} \mathrm{O}_{10}$ & 0.74 & Gallotannin & 0.38 & 331.07 \\
\hline 3 & Pyrogallic acid & $\mathrm{C}_{6} \mathrm{H}_{6} \mathrm{O}_{3}$ & 0.80 & Phenolic acid & 0.49 & \\
\hline 4 & 1-Galloyl-glucose & $\mathrm{C}_{13} \mathrm{H}_{16} \mathrm{O}_{10}$ & 1.01 & Gallotannin & 0.99 & 331.07 \\
\hline 5 & 1-Galloyl-glucose & $\mathrm{C}_{13} \mathrm{H}_{16} \mathrm{O}_{10}$ & 1.27 & Gallotannin & 2.46 & 331.07 \\
\hline 6 & 1-Galloyl-glucose & $\mathrm{C}_{13} \mathrm{H}_{16} \mathrm{O}_{10}$ & 1.58 & Gallotannin & 6.90 & 331.07 \\
\hline 7 & 1-Galloyl-glucose & $\mathrm{C}_{13} \mathrm{H}_{16} \mathrm{O}_{10}$ & 2.22 & Gallotannin & 0.49 & 331.07 \\
\hline 8 & $\begin{array}{l}2,4,5- \\
\text { Trihydeoxybenzaldehyde }\end{array}$ & $\mathrm{C}_{7} \mathrm{H}_{6} \mathrm{O}_{4}$ & 2.34 & Benzaldehyde & 0.43 & 153.02 \\
\hline 9 & 2,6-Di-O-galloyl- $\beta$-Dglucose & $\mathrm{C}_{20} \mathrm{H}_{20} \mathrm{O}_{14}$ & 3.03 & Gallotannin & 0.70 & 483.08 \\
\hline 10 & Polydatin & $\mathrm{C}_{20} \mathrm{H}_{22} \mathrm{O}_{8}$ & 3.53 & Glucoside & 0.73 & 435.13 \\
\hline 11 & 2,6 -Di-O-galloyl- $\beta$-Dglucose & $\mathrm{C}_{20} \mathrm{H}_{20} \mathrm{O}_{14}$ & 3.77 & Gallotannin & 1.64 & 483.08 \\
\hline 12 & Polydatin & $\mathrm{C}_{20} \mathrm{H}_{22} \mathrm{O}_{8}$ & 3.84 & Glucoside & 2.57 & 435.13 \\
\hline 13 & 2,6-Di-O-galloyl- $\beta$-Dglucose & $\mathrm{C}_{20} \mathrm{H}_{20} \mathrm{O}_{14}$ & 4.22 & Gallotannin & 0.63 & 483.08 \\
\hline 14 & $\begin{array}{l}2,3,5,4^{\prime}- \\
\text { Tetrahydroxystilbene- } 2 \\
\text { 3-O- } \beta \text {-Dglucopyranoside }\end{array}$ & $\mathrm{C}_{26} \mathrm{H}_{32} \mathrm{O}_{14}$ & 4.32 & Glucoside & 0.53 & 568.17 \\
\hline 15 & Sesamol & $\mathrm{C}_{7} \mathrm{H}_{6} \mathrm{O}_{3}$ & 4.34 & Hydroquinone derivative & 2.75 & 183.03 \\
\hline 16 & $\begin{array}{l}2,3,5,4 \text { - } \\
\text { Tetrahydroxystilbene- } 2 \\
\text { 3-O- } \beta \text {-Dglucopyranoside }\end{array}$ & $\mathrm{C}_{26} \mathrm{H}_{32} \mathrm{O}_{14}$ & 4.44 & Glucoside & 0.38 & 567.17 \\
\hline 17 & 2,6 -Di-O-galloyl- $\beta$-Dglucose & $\mathrm{C}_{20} \mathrm{H}_{20} \mathrm{O}_{14}$ & 4.65 & Gallotannin & 0.86 & 483.08 \\
\hline 18 & 2,6-Di-O-galloyl- $\beta$-Dglucose & $\mathrm{C}_{20} \mathrm{H}_{20} \mathrm{O}_{14}$ & 4.88 & Gallotannin & 2.63 & 483.08 \\
\hline 19 & 2,6-Di-O-galloyl- $\beta$-Dglucose & $\mathrm{C}_{20} \mathrm{H}_{20} \mathrm{O}_{14}$ & 4.95 & Gallotannin & 3.15 & 483.08 \\
\hline 20 & 2,6-Di-O-galloyl- $\beta$-Dglucose & $\mathrm{C}_{20} \mathrm{H}_{20} \mathrm{O}_{14}$ & 5.16 & Gallotannin & 0.50 & 483.08 \\
\hline 21 & 6'-O-Galloylhomoarbutin & $\mathrm{C}_{20} \mathrm{H}_{22} \mathrm{O}_{11}$ & 5.19 & Galloglucoside & 0.52 & 483.08 \\
\hline 22 & Darendoside A & $\mathrm{C}_{19} \mathrm{H}_{28} \mathrm{O}_{11}$ & 5.48 & Phenethyl alcohol glucosides & 0.39 & 431.16 \\
\hline 23 & Aspidinol & $\mathrm{C}_{12} \mathrm{H}_{16} \mathrm{O}_{4}$ & 5.76 & Simple phenols & 0.78 & 269.10 \\
\hline 24 & Feroxin A & $\mathrm{C}_{17} \mathrm{H}_{24} \mathrm{O}_{8}$ & 5.76 & 3-O Glucoside & 8.44 & 401.14 \\
\hline 25 & Feroxin A & $\mathrm{C}_{17} \mathrm{H}_{24} \mathrm{O}_{8}$ & 5.76 & 3-O Glucoside & 0.44 & 401.14 \\
\hline 26 & $\begin{array}{l}\text { Moracin M-3'-O- } \beta \text { - } \\
\text { Dglucopyranoside }\end{array}$ & $\mathrm{C}_{20} \mathrm{H}_{20} \mathrm{O}_{9}$ & 5.82 & Glucoside & 0.77 & 449.11 \\
\hline 27 & Meliadanoside B & $\mathrm{C}_{15} \mathrm{H}_{20} \mathrm{O}_{8}$ & 5.87 & Glucoside & 1.86 & 373.11 \\
\hline 28 & $1,3,6$-Trigalloyl- $\beta$-Dglucose & $\mathrm{C}_{27} \mathrm{H}_{24} \mathrm{O}_{18}$ & 6.38 & Gallotannin & 2.99 & 635.09 \\
\hline 29 & Feroxidin & $\mathrm{C}_{11} \mathrm{H}_{14} \mathrm{O}_{3}$ & 6.99 & Simple phenol & 1.98 & 329.14 \\
\hline 30 & Thannilignan & $\mathrm{C}_{19} \mathrm{H}_{22} \mathrm{O}_{5}$ & 8.54 & Lignan & 0.47 & \\
\hline 31 & $\begin{array}{l}\text { 3,7-Dihydroxy-2,4- } \\
\text { dimethoxyphenanthren } \\
\text { e-3-O-glucoside }\end{array}$ & $\mathrm{C}_{22} \mathrm{H}_{24} \mathrm{O}_{9}$ & 8.54 & Phenantherene glucoside & 0.62 & 477.14 \\
\hline 32 & Thannilignan & $\mathrm{C}_{19} \mathrm{H}_{22} \mathrm{O}_{5}$ & 8.68 & Lignan & 0.38 & 329.14 \\
\hline 33 & Kuzubutenolide A & $\mathrm{C}_{23} \mathrm{H}_{24} \mathrm{O}_{10}$ & 8.82 & Glucoside & 1.88 & 459.13 \\
\hline 34 & Smilaxin & $\mathrm{C}_{17} \mathrm{H}_{16} \mathrm{O}_{6}$ & 9.09 & Steroid glycoside & 0.50 & 315.09 \\
\hline 35 & Polydatin & $\mathrm{C}_{20} \mathrm{H}_{22} \mathrm{O}_{8}$ & 9.09 & Glycoside & 0.52 & 435.13 \\
\hline 36 & Renifolin & $\mathrm{C}_{18} \mathrm{H}_{24} \mathrm{O}_{7}$ & 9.27 & Glucoside & 0.44 & 397.15 \\
\hline 37 & Protosappanin A & $\mathrm{C}_{15} \mathrm{H}_{12} \mathrm{O}_{5}$ & 9.45 & Dibenzoxocin derivative & 0.37 & 271.06 \\
\hline 38 & $\begin{array}{l}\text { 1-O-Methyl-3,5-Odicaffeoylquin- } \\
\text { ic acid } \\
\text { methyl ester }\end{array}$ & $\mathrm{C}_{27} \mathrm{H}_{28} \mathrm{O}_{12}$ & 9.67 & Phenolic acid & 3.35 & 543.15 \\
\hline 39 & Polydatin & $\mathrm{C}_{20} \mathrm{H}_{22} \mathrm{O}_{9}$ & 9.76 & Glycoside & 0.79 & 435.13 \\
\hline 40 & Feroxidin & $\mathrm{C}_{11} \mathrm{H}_{14} \mathrm{O}_{3}$ & 9.78 & Simple phenol & 2.06 & \\
\hline 41 & $\begin{array}{l}2,3,5,4^{\prime}- \\
\text { Tetrahydroxystilbene-2- } \\
\text { O- } \beta \text {-D-glucopyranoside }\end{array}$ & $\mathrm{C}_{20} \mathrm{H}_{22} \mathrm{O}_{8}$ & 9.94 & Glucoside & 0.37 & 405.12 \\
\hline 42 & $\begin{array}{l}\text { 1-O-Methyl-3,5-Odicaffeoylquin- } \\
\text { ic acid } \\
\text { methyl ester }\end{array}$ & $\mathrm{C}_{27} \mathrm{H}_{28} \mathrm{O}_{12}$ & 9.96 & Phenolic acid & 0.47 & 543.15 \\
\hline 43 & $\begin{array}{l}\text { 2,4,7-Trihydroxy-9,10-dihydro- } \\
\text { phenanthrene }\end{array}$ & $\mathrm{C}_{14} \mathrm{H}_{12} \mathrm{O}_{3}$ & 10.20 & Phenanthrene phenol & 0.87 & 273.08 \\
\hline 44 & Polydatin & $\mathrm{C}_{20} \mathrm{H}_{22} \mathrm{O}_{8}$ & 10.20 & Glycoside & 0.47 & 435.13 \\
\hline
\end{tabular}




\begin{tabular}{|c|c|c|c|c|c|c|}
\hline 45 & $\begin{array}{l}\text { 2,4,7-Trihydroxy-9,10- } \\
\text { dihydrophenanthrene }\end{array}$ & $\mathrm{C}_{14} \mathrm{H}_{12} \mathrm{O}_{3}$ & 10.23 & Phenanthrene phenol & 2.38 & 273.08 \\
\hline 46 & Asebotin & $\mathrm{C}_{22} \mathrm{H}_{26} \mathrm{O}_{10}$ & 10.25 & Dihydrochalcone glucoside & 0.38 & 449.15 \\
\hline 47 & Renifolin & $\mathrm{C}_{18} \mathrm{H}_{24} \mathrm{O}_{7}$ & 10.79 & Glucoside & 0.42 & 397.15 \\
\hline 48 & Asebotin & $\mathrm{C}_{22} \mathrm{H}_{26} \mathrm{O}_{10}$ & 10.92 & Dihydrochalcone glucoside & 0.57 & 449.15 \\
\hline 49 & Asebotin & $\mathrm{C}_{22} \mathrm{H}_{26} \mathrm{O}_{10}$ & 11.33 & Dihydrochalcone glucoside & 0.56 & 449.15 \\
\hline 50 & Dendrocandin C & $\mathrm{C}_{16} \mathrm{H}_{18} \mathrm{O}_{5}$ & 11.47 & Bibenzyl phenols & 0.59 & 289.11 \\
\hline 51 & (R)-Prechrysophanol & $\mathrm{C}_{15} \mathrm{H}_{14} \mathrm{O}_{4}$ & 11.66 & Preanthraquinone & 1.40 & 303.09 \\
\hline 52 & Erigoster A & $\mathrm{C}_{27} \mathrm{H}_{26} \mathrm{O}_{13}$ & 11.74 & Caffeoyl conjugate derivative & 0.38 & 557.03 \\
\hline 53 & $\begin{array}{l}7,2^{\prime}, 3^{\prime} \text {-Trihydroxy-4'- } \\
\text { methoxy-isoflavan }\end{array}$ & $\mathrm{C}_{16} \mathrm{H}_{16} \mathrm{O}_{5}$ & 12.22 & Isoflavane & 1.73 & 287.09 \\
\hline 54 & Phenol & $\mathrm{C}_{6} \mathrm{H}_{6} \mathrm{O}$ & 12.28 & Simple phenol & 0.66 & 139.04 \\
\hline 55 & 4-Hydroxyacetophenone & $\mathrm{C}_{8} \mathrm{H}_{8} \mathrm{O}_{2}$ & 12.75 & Simple phenol & 0.38 & 181.05 \\
\hline 56 & Aspidinol & $\mathrm{C}_{12} \mathrm{H}_{16} \mathrm{O}_{4}$ & 12.77 & Simple phenols & 0.79 & 223.10 \\
\hline 57 & Aspidinol & $\mathrm{C}_{12} \mathrm{H}_{16} \mathrm{O}_{4}$ & 12.77 & Simple phenols & 1.66 & 223.10 \\
\hline 58 & $\begin{array}{l}\text { 3,7-Dihydroxy-2,4- } \\
\text { dimethoxyphenanthren } \\
\text { e-3-O-glucoside }\end{array}$ & $\mathrm{C}_{22} \mathrm{H}_{24} \mathrm{O}_{9}$ & 12.77 & Glucoside & 0.44 & 431.13 \\
\hline 59 & Protosappanin A & $\mathrm{C}_{15} \mathrm{H}_{12} \mathrm{O}_{5}$ & 12.94 & Dibenzoxocin derivative & 0.85 & 271.06 \\
\hline 60 & $\begin{array}{l}\text { 3,7-Dihydroxy-2,4- } \\
\text { dimethoxyphenanthren } \\
\text { e-3-O-glucoside }\end{array}$ & $\mathrm{C}_{22} \mathrm{H}_{24} \mathrm{O}_{9}$ & 12.98 & Phenanthrene glucoside & 1.19 & 431.13 \\
\hline 61 & Albaspidin AA & $\mathrm{C}_{21} \mathrm{H}_{24} \mathrm{O}_{8}$ & 13.32 & Phloroglucinol derivative & 0.62 & 449.15 \\
\hline 62 & p-Tolualdehyde & $\mathrm{C}_{7} \mathrm{H}_{6} \mathrm{O}_{2}$ & 13.44 & Benzenoid & 1.39 & 167.04 \\
\hline 63 & $\begin{array}{l}\text { 2,4,7-Trihydroxy-9,10- } \\
\text { dihydrophenanthrene }\end{array}$ & $\mathrm{C}_{14} \mathrm{H}_{12} \mathrm{O}_{3}$ & 13.45 & Phenanthrene phenol & 7.79 & 273.08 \\
\hline 64 & $\begin{array}{l}\text { 2,7-Dihydroxy-4- } \\
\text { methoxyphenanthrene-2-O- } \\
\text { glucoside }\end{array}$ & $\mathrm{C}_{21} \mathrm{H}_{22} \mathrm{O}_{8}$ & 13.86 & Phenanthrene phenol & 0.73 & 401.12 \\
\hline 65 & Methyl- $\beta$-orsellinate & $\mathrm{C}_{9} \mathrm{H}_{10} \mathrm{O}_{4}$ & 14.91 & Ester phenol & 0.59 & 181.05 \\
\hline 66 & (3R)-3',8-Dihydroxyvestitol & $\mathrm{C}_{16} \mathrm{H}_{16} \mathrm{O}_{6}$ & 14.91 & Isoflavane & 0.74 & 303.09 \\
\hline 67 & Flavanthrinin & $\mathrm{C}_{15} \mathrm{H}_{12} \mathrm{O}_{3}$ & 15.06 & Phenanthrenoid & 1.48 & 285.08 \\
\hline 68 & Haematoxylin & $\mathrm{C}_{16} \mathrm{H}_{14} \mathrm{O}_{6}$ & 15.29 & Phenocyanin & 0.59 & 347.08 \\
\hline 69 & Cyclocurcumin & $\mathrm{C}_{21} \mathrm{H}_{20} \mathrm{O}_{6}$ & 15.81 & Diarylheptanoid & 0.38 & 413.12 \\
\hline 70 & Moracin O & $\mathrm{C}_{19} \mathrm{H}_{18} \mathrm{O}_{5}$ & 15.82 & Glucoside & 1.00 & 371.11 \\
\hline 71 & Methyl- $\beta$-orsellinate & $\mathrm{C}_{9} \mathrm{H}_{10} \mathrm{O}_{4}$ & 16.45 & Ester phenol & 0.68 & 181.05 \\
\hline 72 & $\begin{array}{l}7,2^{\prime}, 3^{\prime} \text {-Trihydroxy-4'- } \\
\text { methoxy-isoflavan }\end{array}$ & $\mathrm{C}_{16} \mathrm{H}_{16} \mathrm{O}_{5}$ & 16.45 & Isoflavane & 2.64 & 287.09 \\
\hline 73 & $\begin{array}{l}7,2^{\prime}, 3^{\prime} \text {-Trihydroxy-4'- } \\
\text { methoxy-isoflavan }\end{array}$ & $\mathrm{C}_{16} \mathrm{H}_{16} \mathrm{O}_{5}$ & 16.45 & Isoflavane & 1.70 & 287.09 \\
\hline 74 & Renifolin & $\mathrm{C}_{18} \mathrm{H}_{24} \mathrm{O}_{7}$ & 16.56 & Glucoside & 0.96 & 351.15 \\
\hline 75 & Thannilignan & $\mathrm{C}_{19} \mathrm{H}_{22} \mathrm{O}_{5}$ & 16.56 & Lignan & 0.51 & 375.14 \\
\hline 76 & Polydatin & $\mathrm{C}_{20} \mathrm{H}_{22} \mathrm{O}_{8}$ & 16.63 & Glucoside & 0.53 & 435.13 \\
\hline
\end{tabular}

Note. RT: Retention Time, $\left[\mathrm{M}^{+}\right]$: Molecular ion mass $(\mathrm{m} / \mathrm{z})$

Table 6: Phytochemical compounds in F2ASP using LC-MS.

\begin{tabular}{|c|c|c|c|c|c|c|}
\hline No. & Compound & Molecular Formula & $\mathrm{RT}(\mathrm{min})$ & Chemical Classes & Responses \% & {$\left[\mathrm{M}^{+}\right]$} \\
\hline 1 & 1-Galloyl-glucose & $\mathrm{C}_{13} \mathrm{H}_{16} \mathrm{O}_{10}$ & 0.43 & Gallotannin & 8.34 & 331.07 \\
\hline 2 & 1-Galloyl-glucose & $\mathrm{C}_{13} \mathrm{H}_{16} \mathrm{O}_{10}$ & 0.80 & Gallotannin & 4.44 & 331.07 \\
\hline 3 & 1-Galloyl-glucose & $\mathrm{C}_{13} \mathrm{H}_{16} \mathrm{O}_{10}$ & 1.06 & Gallotannin & 6.27 & 331.07 \\
\hline 4 & 1-Galloyl-glucose & $\mathrm{C}_{13} \mathrm{H}_{16} \mathrm{O}_{10}$ & 1.33 & Gallotannin & 20.24 & 331.07 \\
\hline 5 & 1-Galloyl-glucose & $\mathrm{C}_{13} \mathrm{H}_{16} \mathrm{O}_{10}$ & 1.57 & Gallotannin & 17.05 & 331.07 \\
\hline 6 & 1-Galloyl-glucose & $\mathrm{C}_{13} \mathrm{H}_{16} \mathrm{O}_{10}$ & 2.21 & Gallotannin & 2.41 & 331.07 \\
\hline 7 & Sesamol & $\mathrm{C}_{7} \mathrm{H}_{6} \mathrm{O}_{3}$ & 4.37 & Hydroquinone derivative & 7.73 & 183.03 \\
\hline 8 & Feroxin A & $\mathrm{C}_{17} \mathrm{H}_{24} \mathrm{O}_{8}$ & 5.56 & 3-O Glucoside & 5.60 & 401.14 \\
\hline 9 & Feroxin A & $\mathrm{C}_{17} \mathrm{H}_{24} \mathrm{O}_{8}$ & 5.75 & 3-O Glucoside & 11.84 & 401.14 \\
\hline 10 & Sinapaldehyde & $\mathrm{C}_{11} \mathrm{H}_{12} \mathrm{O}_{4}$ & 7.03 & Lignin intermediate & 4.90 & 253.07 \\
\hline 11 & Sinapaldehyde & $\mathrm{C}_{11} \mathrm{H}_{12} \mathrm{O}_{4}$ & 9.00 & Lignin intermediate & 3.49 & 253.07 \\
\hline 12 & $\begin{array}{l}7,2^{\prime}, 3^{\prime} \text {-Trihydroxy-4'- } \\
\text { methoxy-isoflavan }\end{array}$ & $\mathrm{C}_{16} \mathrm{H}_{16} \mathrm{O}_{5}$ & 12.48 & Isoflavane & 5.37 & 287.09 \\
\hline 13 & Kukoamine A & $\mathrm{C}_{28} \mathrm{H}_{42} \mathrm{~N}_{4} \mathrm{O}_{6}$ & 16.97 & Benzenoid & 2.32 & 529.30 \\
\hline
\end{tabular}

Note. RT: Retention Time, $\left[\mathrm{M}^{+}\right]$: Molecular ion mass $(\mathrm{m} / \mathrm{z})$ 
intensity compounds were feroxin A (11.84 \%) and sesamol (7.73 \%). Apart from that, the compound with the lowest intensity in F2ASP was kukoamine A (2.32\%), eluted at $16.97 \mathrm{~min}$.

F3ASP eluted the minimum number of compounds as compared to ASP, F1ASP, and F3ASP. Only 5 peaks eluted out including some that existed in redundant as can be seen in Figure 10 while Table 7 listed all the eluted compounds. To be exact, only 3 compounds were identified in F3ASP with negative mode ionization of LC-MS. Only the phenolic groups of gallotannin and simple phenols were identified in this fraction. Again, as in F2ASP, 1-galloyl-glucose was observed with the highest intensity of $34.45 \%$ at $4.14 \mathrm{~min}$. Another highest intensity compound was polydatin ( $30.51 \%)$. The compound with the lowest intensity was feroxin A, by $16.39 \%$.

Table 8 summarizes the phytochemical compounds related to antihypertensive activity which were present in the ASP crude extract and the three derived fractions (F1ASP, F2ASP, and F3ASP). The possible phenolic compounds that have potential in contributing to the antihypertensive effect by $S$. polyanthum are 1-galloyl glucose, polydatin, sesamol, brazilin, eugenol, ellagic acid, kukoamine A and cyclocurcurmin. 1-galloyl glucose or glucogallin is a compound that is present across all fractions as well as in the crude ASP extract. In fact, it becomes the major compound in F2ASP and F3ASP, whereby the concentration of this compound intensified by 30 times as compared to its original crude extract. Previously, this compound was shown to inhibit the angiotensin-converting enzyme I (ACE-I) activity by the formation of chelate complexes within the active site of ACE-I. ${ }^{47}$ Inhibition of this enzyme indicates huge potential in reducing blood pressure and this is actually the mechanism of action of captopril, the positive control drug used in this study. Polydatin is a major compound found in F3ASP, while it is also present in smaller amounts in ASP and F1ASP. Polydatin, a glucoside of resveratrol can upregulate the level of nitric oxide (NO) and it also decreases the levels of endothelin (ET) and angiotensin II and thus depresses blood pressure in pressure-overload rats. ${ }^{48}$ Sesamol which was found in ASP crude extract, F1ASP, and F2ASP was found to exhibit an antihypertensive effect in uninephrectomized deoxycorticosterone acetate (DOCA)-salt-induced hypertensive rats at a specific dosage of $50 \mathrm{mg} / \mathrm{kg}$. ${ }^{49}$ Other than sesamol, brazilin which was found only in ASP crude extract was previously reported to induce vasorelaxation in rat aortic rings through both endothelium-dependent and independent pathway ${ }^{50}$ by activating calcium-dependent nitric oxide synthesis. ${ }^{51}$ Vasorelaxation is one of the main mechanisms of actions that may result in an antihypertensive effect.

Not only these, eugenol which was also found in ASP crude extract was previously reported to relax mesenteric arteries, and thus reducing systemic blood pressure by activating endothelial cell TRPV4 channels. ${ }^{52}$ It was also reported to have significant inhibition on ACE activity by $28 \%$ in the serum of untreated diabetic rats..$^{53}$ Ellagic acid, another phenolic acid compound found in ASP crude extract was

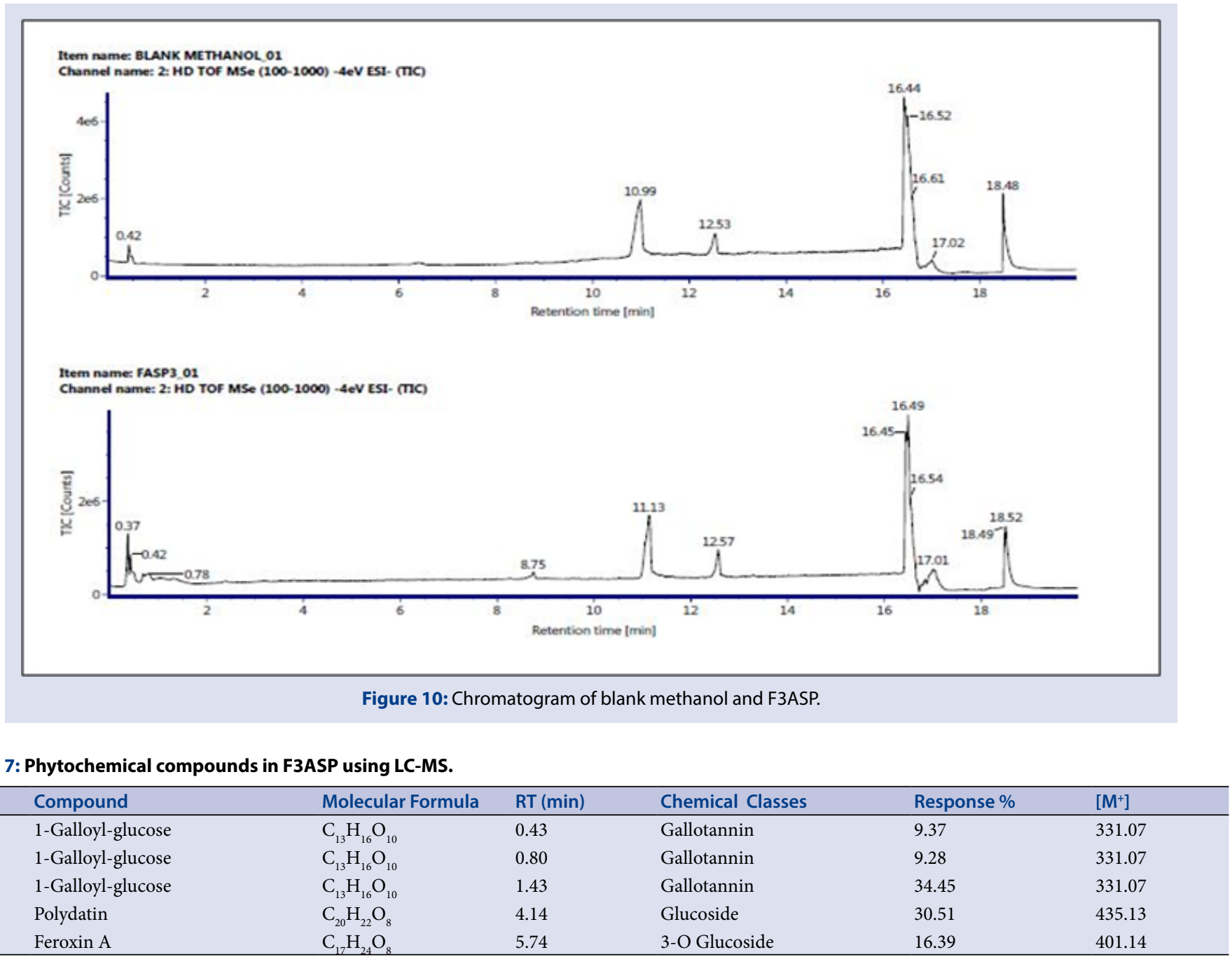

Note. RT: Retention Time, $\left[\mathrm{M}^{+}\right]$: Molecular ion mass $(\mathrm{m} / \mathrm{z})$ 
Table 8. Bioactive phenolic compounds in the crude aqueous extract of $S$. polyanthum leaves and its derived fractions with previous reported activities related to antihypertensive effect.

\begin{tabular}{|c|c|c|c|c|c|}
\hline \multirow{2}{*}{ Compound } & \multirow{2}{*}{ Chemical Structure } & \multicolumn{4}{|c|}{ Highest intensity (\%) } \\
\hline & & ASP & F1ASP & F2ASP & F3ASP \\
\hline 1-galloyl-glucose & & $0.67 \%$ & $6.90 \%$ & $\begin{array}{c}20.24 \% \\
\text { (major compound) }\end{array}$ & $\begin{array}{c}34.35 \% \\
\text { (major compound) }\end{array}$ \\
\hline Polydatin & & $0.29 \%$ & $2.57 \%$ & - & $\begin{array}{c}30.51 \% \\
\text { (major compound) }\end{array}$ \\
\hline Sesamol & & $0.24 \%$ & $2.75 \%$ & $7.73 \%$ & - \\
\hline Brazilin & & $1.19 \%$ & - & - & - \\
\hline Eugenol & & $0.17 \%$ & - & - & - \\
\hline Ellagic acid & & $0.08 \%$ & - & - & - \\
\hline Kukoamine A & & - & - & $2.32 \%$ & - \\
\hline Cyclo-curcumin & & $0.10 \%$ & $0.38 \%$ & - & - \\
\hline
\end{tabular}


able to attenuate $\beta$-nicotinamide adenine dinucleotide phosphate $(\mathrm{NADPH})$ oxidase subunit $\mathrm{p} 47$ phox expression which is responsible for increased vascular oxygen radical, and this can eventually prevent any oxidative stress and reinstate nitric oxide bioavailability. ${ }^{54}$ Nitric oxide is an important endothelium-derived relaxing factor that might cause vasorelaxation, reducing the total peripheral resistance, and this might have contributed to the antihypertensive effect. Furthermore, kukoamine A which was found only in F2ASP was shown to induce hypotension in rats at a dose of $5 \mathrm{mg} / \mathrm{kg}$ when administered intravenously. ${ }^{55}$ Other than that, cyclocurcumin that was found in ASP crude extract and F1ASP in the current study, were previously shown to significantly inhibit the contraction of the vascular muscle of isolated rat aorta ring. ${ }^{56}$

\section{CONCLUSION}

This study found 1-galloyl glucose as the major compound with several other phenolic compounds such as polydatin, sesamol, brazilin, eugenol, ellagic acid, kukoamine $\mathrm{A}$, and cyclocurcumin in the active antihypertensive crude extract and fractions of $S$. polyanthum leaves. These phenolic compounds have proven biological activities related to the antihypertensive effect, thus, they may be in part, responsible for the antihypertensive effect by $S$. polyanthum leaves and thus further isolation is recommended.

\section{ACKNOWLEDGEMENT}

This research is funded by the Ministry of Higher Education, Malaysia with grant number FRGS/1/2018/SKK10/UIAM/02/1. The authors would like to acknowledge the staff at Natural Product Laboratory, Kulliyyah of Science, International Islamic University Malaysia, and the staff from Biomedicine Unit, School of Health Sciences and Animal Research and Service Centre, Universiti Sains Malaysia for providing technical support in carrying out this experiment.

\section{REFERENCES}

1. World Health Organization. A global brief on hypertension: silent killer, global public health crisis: World Health Day 2013. World Health Organization, 2013.

2. Bloch MJ. Worldwide prevalence of hypertension exceeds 1.3 billion. J Am Soc Hypertens 2016;10(10):753-54.

3. Yusufali AM, Khatib R, Islam S, Alhabib KF, Bahonar A, Swidan HM, et al. Prevalence, awareness, treatment and control of hypertension in four Middle East countries. J Hypertens 2017;35(7):1457-64.

4. Sanidas EA, Tzanis G, Papadopoulos D, Barbetseas J, Papademetriou V. Olmesartan worsening known thrombocytopenia. A rare side effect of antihypertensive drugs. Hell J Cardiol 2017;58(1):96-97.

5. Nguyen Q, Dominguez J, Nguyen L, Gullapalli N. Hypertension management: an update. Am Health Drug Benef 2010;3(1):47-56.

6. Ren-Ren B, Xiao-Ming W, Jin-YiX. Current natural products with antihypertensive activity. Chin J Nat Medicines 2015;13(10):721-29.

7. Sukrasno S, Anggadiredja K, Dudi D, Suciatmo AB. Antihypertensive effect of bay leaf extract (Syzygium polyanthum (Wight) Walp., Myrtaceae). Acta Pharmaceut Indonesia 2013;38(4):134-38.

8. Ismail A, Mohamed M, Sulaiman S, Wan AhmadW. Autonomic nervous system mediates the hypotensive effects of aqueous and residual methanolic extracts of Syzygium polyanthum (Wight) Walp. var. polyanthum leaves in anaesthetized rats. Evid-Based Complementary Alternat Med 2013;2013:1-17.

9. Ismail A, Ramli NS, Mohamed M, Wan Ahmad WAN. Acute and subacute antihypertensive effects of Syzygium polyanthum leaf extracts with determination of gallic acid using HPLC analysis. Pharmacogn J 2018;10(4):66371.

10. Wan AhmadWAN, Jamal N, Rahmat UN, Ramli NS, Muhammad NA, Noordin L. Evaluation of Syzygium polyanthum leaves methanol extract as antihypertensive agent in rat. Int J Cardiol 2017;249(S10):1.

11. Ramli N, Muhammad N, Safuan S, Noordin L, Wan Ahmad WAN. Preliminary evaluation on the effect of methanolic extract from Syzygium polyanthum on improvement of hypertensive-renal damage among Spontaneous Hypertensive Rat models. Ann Microsc 2017;16(April):15-22.

12. Mantruad $A$, Pannangpetch $P$, Kongyingyoes $B$, Kukongviriyapan $U$, Chuanta $S$, Nakmareong $S$, et al. Roselle extract and gallic acid improve vascular reactivity of diabetic rats. Srinagarind Med J 2010;25 (Suppl):257-61.
13. Jin L, Lin MQ, Piao ZH, Cho JY, Kim GR, Choi SY, et al. Gallic acid attenuates hypertension, cardiac remodeling, and fibrosis in mice with NG-nitro-L-arginine methyl ester-induced hypertension via regulation of histone deacetylase 1 or histone deacetylase 2. J Hypertens 2017;35(7):1502-12.

14. Rahim ENAA, Ismail A, Omar MN, Rahmat UN, AhmadWANW. GC-MS analysis of phytochemical compounds in Syzygium polyanthum leaves extracted using ultrasound-assisted method. Pharmacogn J 2018;10(1):110-19.

15. Trendafilova A, Chanev C, Todorova M. Ultrasound-assisted extraction of alantolactone and isoalantolactone from Inula helenium roots. Pharmacogn Mag 2010;6(23):234-37.

16. Muniz-Marquez DB, Martinez-Avila GC, Wong-Paz JE, Belmares-Cerda R, Rodriguez-Herrera R, Aguilar CN. Ultrasound-assisted extraction of phenolic compounds from Laurus nobilis L. and their antioxidant activity. Ultrason Sonochem 2013;20(5):1149-54.

17. Annegowda H, Bhat R, Min-Tze L, Karim A, Mansor S. Influence of sonication treatments and extraction solvents on the phenolics and antioxidants in star fruits. J Food Sci Technol 2012:49(4):510-14.

18. Weller MG. A unifying review of bioassay-guided fractionation, effect-directed analysis and related techniques. Sensors 2012;12(7):9181-209.

19. Muhamad N, Muhmed SA, Yusoff MM, Gimbun J. Influence of solvent polarity and conditions on extraction of antioxidant, flavonoids and phenolic content from Averrhoa bilimbi. J Food Sci Eng 2014;4(2014):255-60.

20. Bajpai VK, Majumder R, Park JG. Isolation and purification of plant secondary metabolites using column-chromatographic technique. Bangladesh $J$ Pharmacol 2016;11(4):844-48.

21. Pirrung MC. The synthetic organic chemist's companion. New Jersey: John Wiley \& Sons Inc., p. 104-105; 2007.

22. Mohrig JR, Alberg D, Hofmeister G, Schatz PF, Hammond CN. Laboratory techniques in organic chemistry. New York: Macmillan Higher Education, p. 2014.

23. Parasuraman S, Raveendran R. Measurement of invasive blood pressure of rats. J Pharmacol Pharmacother 2012;3(2):172-77.

24. Abdulazeez MA, Ibrahim S, Ameh DA, Ayo JO, Carvalho L, Manosroi J, et al. Bioassay-guided fractionation and antihypertensive properties of fractions and crude extracts of Peristrophe bicalyculata (Retz) Nees. Acta Pol Pharm 2015;72(2):319-28.

25. Blainski A, Lopes GC, De Mello JCP. Application and analysis of the folin ciocalteu method for the determination of the total phenolic content from Limonium brasiliense L. Molecules 2013;18(6):6852-65.

26. Huang $D$, Ou B, Prior RL. The chemistry behind antioxidant capacity assays. $J$ Agric Food Chem 2005;53(6):1841-56

27. Terpinc P, Cigić B, Polak T, Hribar J, Požrl T. LC-MS analysis of phenolic compounds and antioxidant activity of buckwheat at different stages of malting. Food Chem 2016;210(9-17.

28. Jumaat SR, Tajuddin SN, Sudmoon R, Chaveerach A, Abdullah UH, Mohamed R. Chemical constituents and toxicity screening of three aromatic plant species from Peninsular Malaysia. BioResources 2017;12(3):5878-95.

29. Sulmartiwi L, Pujiastuti D, Tjahjaningsih W. Potential of mangrove Avicennia rumphiana extract as an antioxidant agent using multilevel extraction. IOP Conf Ser: Earth Environ Sci 2018;137(2018).

30. Tiwari P, Kumar B, Kaur M, Kaur G, Kaur H. Phytochemical screening and extraction: a review. Int Pharm Sci 2011;1(1):98-106.

31. Widyawati PS, Budianta TDW, Kusuma FA, Wijaya EL. Difference of solvent polarity to phytochemical content and antioxidant activity of Pluchea indicia Less leaves extracts. Int J Pharmacogn Phytochem Res 2014;6(4):850-55.

32. Do QD, Angkawijaya AE, Tran-Nguyen PL, Huynh LH, Soetaredjo FE, Ismadji $\mathrm{S}$, et al. Effect of extraction solvent on total phenol content, total flavonoid content, and antioxidant activity of Limnophila aromatica. J Food Drug Anal 2014;22(3):296-302.

33. Dent M, Dragović-Uzelac V, Penić M, BosiljkovT, Levaj B. The effect of extraction solvents, temperature and time on the composition and mass fraction of polyphenols in Dalmatian wild sage (Salvia officinalis L.) extracts. Food Technol Biotechnol 2013;51(1):84-91.

34. Dhawan D, Gupta J. Research article comparison of different solvents for phytochemical extraction potential from datura metel plant leaves. Int J Biol Chem 2017;11(1):17-22.

35. Fiege $H$, Voges HW, Hamamoto T, Umemura $S$, I wata T, Miki H, et al. Phenol derivatives. Weinhem: Wiley-VCH Verlag GmbH \& Co. KGaA, p. 2000.

36. Coskun O. Separation techniques: chromatography. North Clin Istanb 2016;3(2):156.

37. Tahara K, Nishiguchi M, Frolov A, Mittasch J, Milkowski C. Identification of UDP glucosyltransferases from the aluminum-resistant tree Eucalyptus camaldulensis forming $\beta$-glucogallin, the precursor of hydrolyzable tannins. Phytochem 2018;152(August2018):154-61. 
38. DeMers D, Wachs D. Physiology, Mean Arterial Pressure. StatPearls: StatPearls Publishing; 2020.

39. Habib GB. Chapter 44 - Hypertension. In: Levine GN, editor. Cardiology Secrets (Third Edition). Philadelphia: Mosby; 2010. p. 285-92.

40. Lufuluabo LG, Moke LE, Bongo GN, Liyongo Cl, Ashande CM, Sapo BS, et al. A review on the Phytochemistry and Pharmacology of Psidium guajava L.(Myrtaceae) and Future direction. Discovery Phytomedicine 2018:5(2):7-13.

41. Idris B, Asmawi MZ, Nasiba US, Mahmud R, Abubakar K. Antihypertensive and vasorelaxant effect of Alstonia scholaris stem bark extracts and fractions. Int J Pharmacol 2015;11(4):327-34

42. López-Froilán R, Hernández-Ledesma B, Cámara M, Pérez-Rodríguez ML. Evaluation of the antioxidant potential of mixed fruit-based beverages: a new insight on the folin-ciocalteu method. Food Anal Methods 2018:11(10):2897906.

43. Sánchez-Rangel JC, Benavides J, Heredia JB, Cisneros-Zevallos L, JacoboVelázquez DA. The Folin-Ciocalteu assay revisited: improvement of its specificity for total phenolic content determination. Anal Methods 2013;5(21):5990-99.

44. Wong SP, Leong LP, Koh JHW. Antioxidant activities of aqueous extracts of selected plants. Food Chemistry 2006;99(775-83.

45. Safriani N, Arpi N, Erfiza NM. Potency of curry (Murayya koeniigi) and salam (Eugenia polyantha) leaves as natural antioxidant sources. Pak J Nutr 2015;14(3):131.

46. Har L, Ismail I. Antioxidant activity, total phenolics and total flavonoids of Syzygium polyanthum (Wight) Walp leaves. International Journal of Medicinal Aroma Plants 2012;2(2):219-28.

47. Ahmed ZB, Yousfi M, Viaene J, Dejaegher B, Demeyer K, Mangelings D, et al. Potentially antidiabetic and antihypertensive compounds identified from Pistacia atlantica leaf extracts by LC fingerprinting. J Pharm Biomed Anal 2018:149(547-56.
48. Du Q-H, Peng C, Zhang H. Polydatin: a review of pharmacology and pharmacokinetics. Pharm Biol 2013;51(11):1347-54.

49. Hemalatha G, Pugalendi KV, Saravanan R. Modulatory effect of sesamol on DOCA-salt-induced oxidative stress in uninephrectomized hypertensive rats. Mol Cell Biochem 2013;379(1-2):255-65.

50. Yan Y, Chen Y-c, Lin Y-h, Guo J, Niu Z-r, Li L, et al. Brazilin isolated from the heartwood of Caesalpinia sappan $\mathrm{L}$ induces endothelium-dependent andindependent relaxation of rat aortic rings. Acta pharmacologica Sinica 2015;36(11):1318-26.

51. Nirmal NP, Rajput MS, Prasad RG, Ahmad M. Brazilin from Caesalpinia sappan heartwood and its pharmacological activities: a review. Asian Pac J Trop Med 2015;8(6):421-30.

52. Peixoto - Neves D, Wang Q, Leal - Cardoso JH, Rossoni LV, Jaggar JH. Eugeno dilates mesenteric arteries and reduces systemic BP by activating endothelial cell TRPV 4 channels. Br J Pharmacol 2015;172(14):3484-94

53. Mnafgui K, Kaanich F, Derbali A, Hamden K, Derbali F, Slama S, et al. Inhibition of key enzymes related to diabetes and hypertension by eugenol in vitro and in alloxan-induced diabetic rats. Arch Physiol Biochem 2013;119(5):225-33.

54. Berkban T, Boonprom P, Bunbupha S, Welbat JU, Kukongviriyapan U, Kukongviriyapan V, et al. Ellagic acid prevents L-NAME-induced hypertension via restoration of eNOS and p47phox expression in rats. Nutrients 2015:7(7):526580.

55. Funayama S, Yoshida K, Konno C, Hikino H. Structure of kukoamine A a hypotensive principle of Lycium chinense root barks. Tetrahedron Lett 1980:21(14):1355-56.

56. Kim K, Kim J-J, Jung Y, Noh J-Y, Syed AS, Kim CY, et al. Cyclocurcumin, an antivasoconstrictive constituent of Curcuma longa (Turmeric). J Nat Prod 2017:80(1):196-200.

\section{GRAPHICAL ABSTRACT}

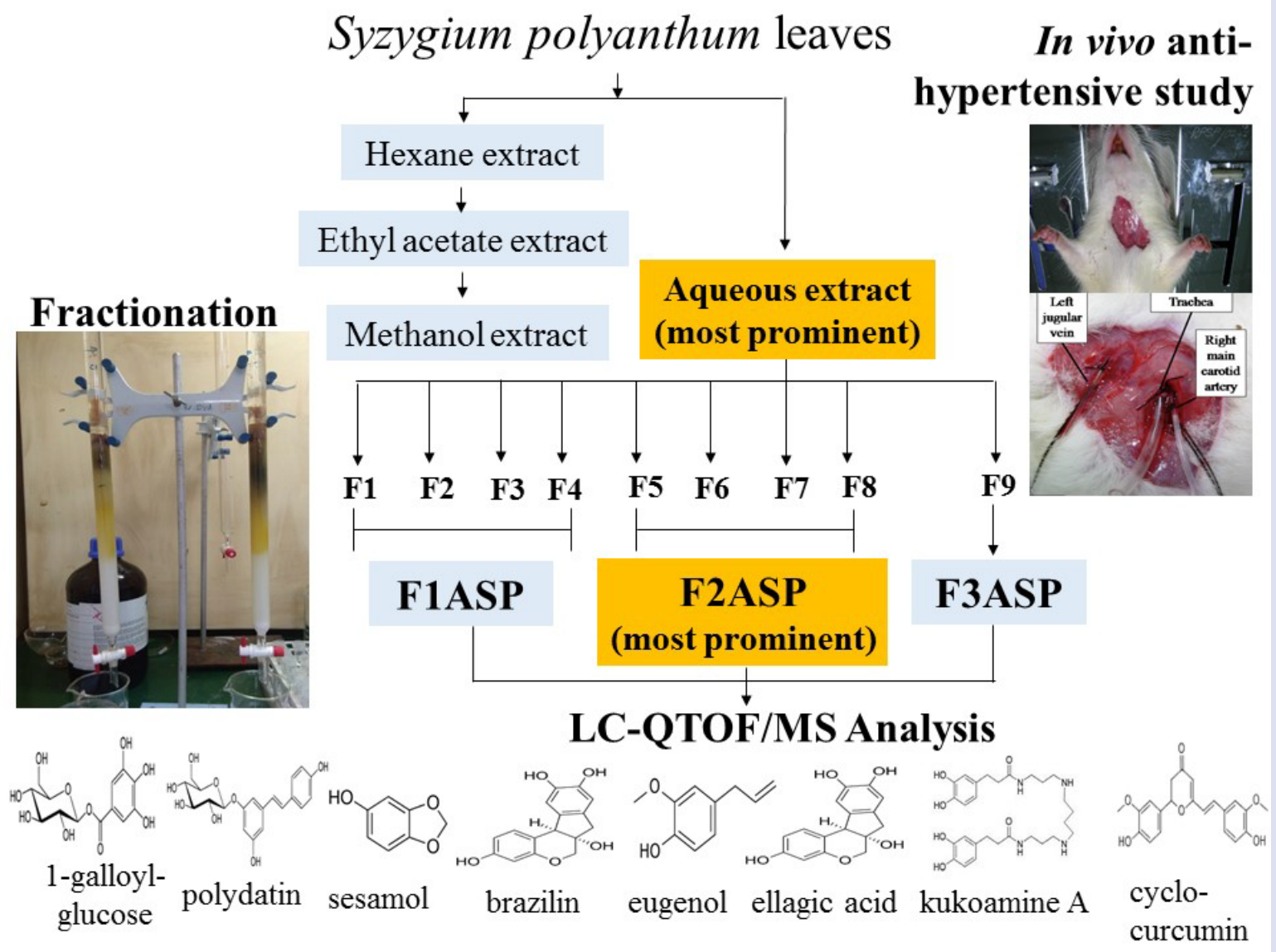




\section{ABOUT AUTHORS}

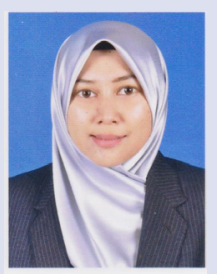

Azlini Ismail: Azlini Ismail is an Assistant Professor (senior lecturer) at Department of Fundamental Dental and Medical Sciences, Kulliyyah of Dentistry, International Islamic University Malaysia (IIUM). Her research interests include cardiovascular pharmacology, pharmacognosy, natural product, and traditional medicine.

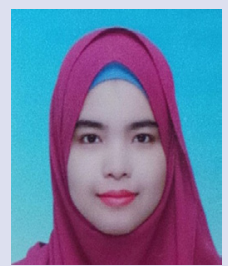

Erlena Nor Asmira Abdul Rahim: Erlena Nor Asmira is an MSc Biotechnology (IIUM) and Bsc Chemistry (UiTM Pahang) holder currently working as Sales Executive cum. Biotechnologist at Asia Botanicals Sdn Bhd. Her current work is related with food supplement, natural products and traditional medicine.

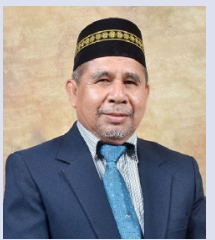

Muhammad Nor Omar: Muhammad Nor Omar is a professor at Department of Biotechnology, Kulliyyah (Faculty) of Science, International Islamic University Malaysia (IIUM). He focus his research in the area of natural products besides developing products from palm oil oleochemicals.

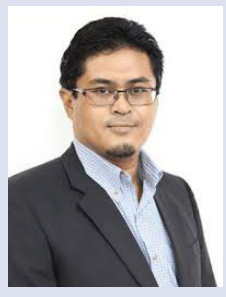

Wan Amir Nizam Wan Ahmad: Wan Amir Nizam Wan Ahmad is currently a Senior Lecturer at School of Health Sciences, Universiti Sains Malaysia. His research interest include natural product pharmacology, cardiovascular disease and animal model of disease.

Cite this article: Ismail A, Rahim ENAA, Omar MN, Wan Ahmad WAN. Antihypertensive Assay-Guided Fractionation of Syzygium polyanthum Leaves and Phenolics Profile Analysis Using LC-QTOF/MS. Pharmacogn J. 2020;12(6)Suppl:1670-92. 